Received Date : 07-Dec-2013

Revised Date : 24-Apr-2015

Accepted Date : 26-May-2015

Article type : Original Article

\title{
Subsidence and thermal history of an inverted Late Jurassic-Early Cretaceous extensional basin (Cameros, North-central Spain) affected by very low- to low-grade metamorphism
}

Omodeo-Salé, S. ${ }^{1, a *}$, Salas, R. ${ }^{2}$, Guimerà, J. ${ }^{3}$, Ondrak, R. ${ }^{4}$, Mas, R. ${ }^{5}$, Arribas, J. ${ }^{1}$, SuárezRuiz, I. ${ }^{6}$, Martinez, L. ${ }^{7}$

1. Departamento de Petrología y Geoquímica, UCM, IGEO (UCM-CSIC), Madrid (Spain)

2. Departament de Geoquímica, Petrologia i Prospecció Geològica, Universitat de Barcelona (Spain)

3. Departament de Geodinàmica i Geofísica, Universitat de Barcelona (Spain)

4. Organic Geochemistry, GFZ, German Research Centre for Geosciences, Potsdam (Germany)

5. Departamento de Estratigrafía, UCM, IGEO (UCM-CSIC), Madrid (Spain)

6. Instituto Nacional del Carbón, INCAR-CSIC, Oviedo (Spain)

7. EOST, Université de Strasbourg, Nancy (France)

${ }^{a}$ Actual address: Direction Géosciences, IFPEN, Rueil Malmaison (France)

$\left(^{\star}\right)$ corresponding author: silvia.omodeo@geo.ucm.es

\section{Abstract}

The Cameros Basin (North Spain) is a Late Jurassic-Early Cretaceous extensional basin, which was inverted during the Cenozoic. It underwent a remarkable thermal evolution, as indicated by the record of anomalous high temperatures in its deposits. In this work the subsidence and thermal history of the basin is reconstructed, using subsidence analysis and 2D thermal modeling.

This article has been accepted for publication and undergone full peer review but has not been through the copyediting, typesetting, pagination and proofreading process, which may lead to differences between this version and the Version of Record. Please cite this article as doi: 10.1111/bre.12142

This article is protected by copyright. All rights reserved. 
Tectonic subsidence curves provide evidence of the occurrence of two rapid subsidence phases during the syn-extensional stage. In the first phase (Tithonian-Early Berriasian), the largest accommodation space was formed in the central sector of the basin, whereas in the second (Early Barremian-Early Albian), it was formed in the northern sector. These rapid subsidence phases could correspond to relevant tectonic events affecting the Iberian Plate at that time. By distinguishing between the initial and thermal subsidence and defining their relative magnitudes, Royden's (1986) method was used to estimate the heat flow at the end of the extensional stage. A maximum heat flow of $60-65 \mathrm{~mW} / \mathrm{m}^{2}$ is estimated, implying only a minor thermal disturbance associated with extension. In contrast with these data, very high vitrinite reflectance, anomalously distributed in some case with respect to the typical depthvitrinite reflectance relation, was measured in the central-northern sector of the basin.

Burial and thermal data are used to construct a 2D thermal basin model, to elucidate the role of the processes involved in sediment heating. Calibration of the thermal model with the vitrinite reflectance (\%Ro) and fluid inclusion ( $\mathrm{FI})$ data indicates that in the central and northern sectors of the basin, an extra heat source, other than a typical rift, is required to explain the observed thermal anomalies. The distribution of the \%Ro and $\mathrm{FI}$ values in these sectors suggests that the high temperatures and their distribution are related to the circulation of hot fluids. Hot fluids were attributed to the hydrothermal metamorphic events affecting the area during the early post-extensional and inversion stages of the basin.

\section{Key words:}

Subsidence history, heat flow, 2D thermal model, Fluid circulation, Cameros Basin

\section{INTRODUCTION}

The opening of the Western Tethys and North Atlantic domains in late Jurassic to early Cretaceous times caused left-lateral movement of the Iberian relative to the European plates (Arche \& López-Gómez, 1996; Salas et al., 2001; Vera, 2001; Vergés \& Garcia-Senz, 2001; Jammes et al., 2010). A wide corridor of transtensional deformation progressively formed along the Iberian plate, developing distinct extensional systems (e.g. Tugend et al., 2015). The extension was asynchronous along the plate and the associated crustal thinning reduces from the Bay of Biscaly-Parentis and Pyrenean-Basque-Cantabrian domains to the Central Iberian extensional system (Tugend et al., 2015). In this context, in the westernmost part of the Central Iberian domain the Cameros Basin originated during the Tithonian to Early Albian, (Mas et al., 1993; Guimerà et al., 1995; Salas et al., 2001).

This article is protected by copyright. All rights reserved. 
The Cameros Basin (North-central Spain) records a remarkable and complex tectonosedimentary evolution and thermal history, making the study of this basin very useful for the comprehension of the geodynamic evolution of the of the Iberian Plate area. In the central Iberian domain the Cameros Basin experienced the highest subsidence (Salas et al., 2001) with the deposition of up to $6500 \mathrm{~m}$ of mainly continental sediments in fewer than 50 My (e.g. Mas et al., 1993). Furthermore, in the northeastern sectors of the basin, part of the synextensional succession was affected by very low- to low-grade metamorphism. The origin and distribution of the anomalously high temperatures recorded have been the subject of substantial debate over the past three decades. Several inorganic proxies (mineral paragenesis, illite crystallinity and fluid inclusions) have been used to characterize the metamorphism. Some authors (Guiraud \& Séguret, 1985; Goldberg et al., 1988; CasasSainz, 1992; Mata et al., 2001; Del Río et al., 2009; Casas et al., 2012) have attributed this metamorphism to burial. However, others (Casquet et al., 1992; Barrenechea et al., 1995; Mantilla-Figueroa et al., 1998; Alonso-Azcárate et al., 1999; Barrenechea et al., 2001; Ochoa et al., 2007; González-Acebrón et al., 2011; González-Acebrón et al., 2012) have interpreted the metamorphism as having a hydrothermal and allochemical origin. The present study is an attempt to improve the understanding of the thermal evolution of the Cameros Basin. To determine the thermal stages of the deposits of the basin, for the first time, accurate vitrinite reflectance (\%Ro, VR) measurements were performed, providing information on the real temperatures reached in the basin infill. There was an anomalous pattern of the vitrinite reflectance with the depth, compared to typical extensional basins. To improve temperature history reconstruction, \%Ro data were also combined with fluid inclusions data, as the latter are the only direct evidence of the circulation of palaeofluids (Goldstein \& Reynolds, 1994).

The reconstruction of the thermal history of a basin requires knowledge of the paleo-heat flow and its variation associated with basin formation. In the case of ancient basins, such data can be obtained through subsidence analysis and estimation of the level of initial and thermal subsidence. Therefore, in addition to comparative studies of vitrinite reflectance, in this work the subsidence analysis of the basin was performed.

As the Cameros Basin is an ancient uplifted and partially eroded continental extensional basin, a number of less common constraints are required (e.g., the amount of material eroded, the age of syn-extensional sequences, and the initial crust and mantle lithospheric thicknesses) to model its thermal history. Therefore, the results obtained herein require a critical interpretation. Despite the numerous uncertainties, this study can considerably improve the understanding of the complex thermal history of the Cameros Basin by estimating the heat flow range at the end of the extension phase and comparing the \%Ro

This article is protected by copyright. All rights reserved. 
data with thermal modeling results. Additionally, relevant data for the comprehension of the geodynamic evolution of the Iberian Plate are provided.

\section{GEOLOGICAL SETTING}

The Cameros Basin belongs to the north-western Iberian Chain (Fig. 1), an intraplate foldand-thrust belt that originated during Alpine contraction, which inverted the Mesozoic Iberian Extensional System (e.g., Salas \& Casas, 1993; Salas et al., 2001). The Cameros Basin formed during the Tithonian to Early Albian and it was inverted in the middle to late Eocene (Salas et al., 2001).

During its evolution the Cameros Basin was affected by two hydrothermal metamorphic events. The first metamorphic event occurred during the early post-extensional stage (Late Albian-Coniacian) and it was especially recorded in the northern sector of the basin. A maximum temperature of more than $350^{\circ} \mathrm{C}$ has been estimated for this event (Casquet et al., 1992). The second event, Early-Middle Eocene in age, has been recorded in different sectors of the basin and maximum temperatures ranged from 280 to $305^{\circ} \mathrm{C}$ (Mantilla-Figueroa et al., 1999; 2002; González-Acebrón et al., 2011).

At present, the Cameros Basin is contained in the Cameros Thrust-sheet (Guimerà et al., 1995), which comprises the extensional and post-extensional sedimentary infill of the basin, its Jurassic and Triassic substratum and the Variscan basement (Fig. 1). The most relevant structural features are the thrusts that bound the Cameros structural unit to the north and south (Guimerà et al., 1995) (Fig. 1). The basin infill is merely gently folded, and it was apparently unaffected by relevant deformation.

\subsection{Basin infill}

The syn-extensional sedimentary record (Late Tithonian to the Early Albian) mainly consists of continental, predominantly fluvial, lacustrine and tide-influenced depositional systems (Mas et al., 1993, 2003, 2011). The syn-extensional deposits have been divided into eight depositional sequences (DS) (Fig. 1) (Mas et al., 2002; Mas et al., 2011), which are formed by different lithological units (Fig. 2). With respect to the age, scattered age data are available from charophytes, ostracods and palynological associations in the continental record as well as from dasycladacean algae and a few foraminifera in the rare marine incursions (Brenner, 1976; Salomon, 1982; Guiraud \& Séguret, 1985; Schudack, 1987; Alonso \& Mas, 1993; Martín-Closas \& Alonso-Millán, 1998; Suarez-Gonzalez et al., 2013).

Underlying the syn-extensional units, and separated by a regional unconformity, there are approximately 1-1.5 km of pre-extensional Triassic and marine Jurassic deposits, which

This article is protected by copyright. All rights reserved. 
represent the substratum of the basin. Draping the Cameros Basin infill, there is a package of continental deposits passing upward into a shallow-marine carbonate platform (Platt, 1989; Alonso \& Mas, 1993; Salas et al., 2001; García \& Mas, 2004) (Fig. 1, 2), with a total thickness of $600-800 \mathrm{~m}$. This post-extensional succession is only preserved in the southwestern sector of the basin, but its thickness is unlikely to have varied substantially over the rest of the basin (e.g., Omodeo Salé et al., 2014) (Fig. 1).

\section{METHODOLOGY}

In order to understand the origin of the thermal anomalies observed in the Cameros Basin, a $2 \mathrm{D}$ numerical model of the thermal history of the basin was performed. For thermal modeling, an estimation of the heat flow affecting the basin is necessary. Such information was obtained with subsidence analysis. Vitrinite reflectance data (VR, \%Ro), punctually complemented by fluid inclusions data $(\mathrm{FI})$, were used to evaluate the thermal stage of the basin infill deposits and to validate the thermal model. For subsidence analysis and 2D thermal modeling the restoration to the pre-inversion state of balanced geological crosssection of the basin was used (Omodeo Salé et al., 2014) (Fig. 3b and Fig. 1 for location). The reconstructed section crosses the basin from the northern main thrust to the southern back-thrust, intersecting the syn-extensional units in the recognized depocentral areas (Fig. 1).

\subsection{Subsidence analysis and heat flow estimation}

Curves for sediment accumulation vs. time (sediment-loaded, total subsidence) and for the tectonic subsidence (backstripped/water loaded) were determined for eight virtual wells along the restored cross-section (Fig. 3b). Reconstructed well stratigraphies are summarized in Fig. 4. Subsidence curves were constructed from the base of the Kimmeridgian (155.6 My) to the end of the Cretaceous (65.5 My). For the syn-extensional stage, the units correspond to the depositional sequences defined by Mas et al. $(2002,2003,2011)$. These depositional sequences represent the units whose boundaries can be approximately dated and traced throughout the basin. The post-extensional sedimentary record is represented by two units, a 100-m thick sandstone unit, corresponding to the Utrillas Fm (Late Albian), and a 550-m thick unit that mainly consists of shallow-marine platform carbonates, referred to as "Upper Cretaceous". The numerical age data used in this study (Fig. 1, Table 1) are those from Gradstein et al. (2004) and Ogg et al. (2008). To simplify the process of lithological assignment for decompaction and backstripping, each Formation and Group was represented by the percentages of three main lithologies (limestone, sandstone and shale,

This article is protected by copyright. All rights reserved. 
Table 1). In the virtual wells, the simplified lithology was proportionally calculated with respect to the thickness of the Formation or Group considered (Fig. 4 and Table 2).

The burial history diagrams were obtained using the subsidence software of Waltham (2001). The variation in the thickness and paleo-depth of each sediment layer over time was sequentially calculated by removing the overlying layers and decompacting each layer. Decompaction was calculated using empirical porosity/depth equations (Sclater \& Christie, $1980)$ for the specific lithology of each layer. The initial porosity $\left(\Phi_{0}\right)$ and compact factor (c) used for decompaction refer to the values proposed by Sclater and Christie (1980) and Schmoker and Halley (1982), which were proportionally calculated with respect to the lithological composition of each unit (Table 2). A "total subsidence" curve for each virtual well was obtained, providing information on the accommodation space formed over time. Paleobathymetry and eustasy corrections were omitted because of the continental to very shallow-water/coastal nature of the deposits. Via backstripping, the (water-loaded) tectonic subsidence was obtained. The backstripping equation was proposed by Watts \& Ryan (1976), assuming local isostatic compensation (Airy model).

An estimation of the surface heat flow $\left(\mathrm{mW} / \mathrm{m}^{2}\right)$ at the end of the extensional stage was obtained with the graphical approach developed by Royden \& Keen (1980) and Royden (1986), in which the initial subsidence and thermal subsidence values were used (Table 3). Estimation of the heat flow was made for each virtual well (Table 3).

\subsection{Vitrinite reflectance and thermal modeling}

To determine the thermal stage of the basin infill, vitrinite reflectance was measured on shale and fine grained carbonate organic-rich deposits outcropping throughout the basin (Fig. 1). Nineteen polished sections were analyzed at the INCAR laboratory (Oviedo, Spain) using reflected white light and an oil immersion objective (50x) with an MPV-Combi-Leitz optical microscope. ISO norms (ISO-7404-2, 2009; ISO-7404-5, 2009) and ICCP nomenclature (ICCP, 1998, 2001) were applied. For very mature samples, the organic matter was examined under polarized light incorporating a 1 - $\lambda$-retarder plate that provides a better definition of the anisotropy properties. Therefore, high reflectance vitrinite macerals could be differentiated from inertinite and/or solid bitumens particles. The obtained \%Ro mean value, indicated in Table 4, for each sample is estimated considering both the \%Ro mean value and the \%Ro frequency distribution (standard deviation).

To determine if the thermal conditions indicated by VR and FI can be reached by burial, a $2 \mathrm{D}$ numerical thermal model was used and compared with the measured data. The model

was reconstructed with the PetroMod software of Schlumberger. The principles and applications of these simulations have been explained, e.g., by Büker et al., (1995), Poelchau

This article is protected by copyright. All rights reserved. 
et al., (1997), and Yalcin et al., (1997). As far as heat flow is concerned, additionally than considering the heat flow calculated by Royden's method, different scenarios were tested. To build the thermal model, the basin history was divided into a succession of "events", which correspond to the pre-extensional, syn-extensional and post-extensional units used in the subsidence analysis. The restored section of the basin (Fig. 3b) was assumed as the geological model. The facies used for modeling are displayed in Fig. 5 and refer to the simplified lithologies in Table 1.

The $2 \mathrm{D}$ thermal model was validated by comparing the measured vitrinite reflectance data (\%Ro) with the vitrinite reflectance values predicted by the EASY \%Ro model (Sweeney \& Burnham, 1990). In accordance with the geographical and reconstructed stratigraphical positions (Fig. 3a), vitrinite reflectance samples were plotted on the restored section at the inferred paleo-depth (Fig. 5). The measured \%Ro values were grouped and projected into six calibration wells (Fig. 5). In cases where the measured \%Ro values differed markedly from the trend represented by the curve, the burial history variables (depositional thickness or erosion) and/or the basal heat flow needed to be adjusted until the calibration improved. Homogenization temperatures (Th), measured in primary fluid inclusions (González-Acebrón, 2013), were punctually used to complement the vitrinite reflectance data. To display fluid inclusion data, two calibration wells were defined, where the measured Th was compared with the temperatures predicted by the model at the corresponding depth.

\subsection{Estimation of errors}

It is difficult to obtain reliable results from subsidence analysis and thermal modeling in basins that have been totally inverted, partially eroded and affected by a complex thermal history. Therefore, many assumptions and approximations need to be made.

The reconstruction of the geometry of the basin (e.g., Omodeo Salé et al., 2014) shows that much of the basin infill has been eroded. Reconstruction of the thickness and geometries of the eroded part of the section was performed by projection into the cross-section of many thickness data measured in the adjacent areas (Omodeo Salé et al., 2014). As different authors have obtained similar results (ca. $5 \mathrm{~km}$ by Muñoz and Casas, 1997 and Casas and Gil, 1998 and $5.500 \mathrm{~m}$ by Mas et al., 1993 and Omodeo Salé et al., 2014), the eroded thickness assumed in this work can be considered a plausible approximation. However, a possible error of $\pm 1000 \mathrm{~m}$ in the results has to be considered.

This article is protected by copyright. All rights reserved. 
Due to the scarce fossils contained in the continental and transitional-marine deposits filling the basin, the dating of the units is another relevant source of uncertainty. Given the heterogeneity of the basin stratigraphy, lithology assignment needs to be simplified (Table 1). Lithologies were determined considering both the outcrop data and numerous sedimentological data collected by previous authors (e.g., Mas et al., 2011 and references therein). For the eroded part, lithologies were extrapolated from field data. Simplifications concerning lithology assignment imply potential errors in the backstripping. However, potential errors introduced by age and lithology assignment are clearly subordinate compared to those associated with the reconstruction of the eroded part of the basin infill.

Royden's (1986) method, used to estimate the maximum heat flow at the end of the extension, implies many simplifications and assumptions (e.g., instantaneous extension, no lateral heat loss, zero flexural strength of the lithosphere, etc.). In the Cameros Basin, a crustal thickness before stretching of $35 \mathrm{~km}$ and a lithosphere thickness of $125 \mathrm{~km}$ were assumed based on data provided on Simancas et al. (2003). Minor deviations from these values did not seem to have relevant consequences on the results (Royden, 1986). With all these assumptions, the results obtained herein, concerning the heat flow, have to be considered as a first approximation.

Finally, conventional thermal modeling software has significant limitations, which makes it difficult to perform an accurate reconstruction of the thermal history of a basin. In fact, the advective heat transport (e.g., circulation of hot fluids) cannot be simulated.

\section{RESULTS}

\subsection{Subsidence pattern and heat flow}

Curves of the total and tectonic subsidence were obtained for every virtual well (Fig. 6). Total subsidence curves show that at the end of the syn-extensional and post-extensional stages (65.5 My), the areas of maximum accommodation space correspond to the Castillejo and Yanguas wells $(6800-6900 \mathrm{~m})$. In contrast, the Lazaro and Fuentetoba wells mark the area where the lowest accommodation space was created (3300-3700). Intermediate values of subsidence were recorded in the areas represented by the rest of the wells.

Via backstripping, values for tectonic subsidence between 1000 and $2000 \mathrm{~m}$ were determined. In all virtual wells, the initial subsidence (from 150.8 to $108.7 \mathrm{My}$ ) was distinguished from the thermal subsidence (from 108.7 to the end of the Cretaceous) (Fig. 6).

This article is protected by copyright. All rights reserved. 
The initial subsidence varies between 800 and $2000 \mathrm{~m}$ along the section (Table 3), and the thermal subsidence ranges from 110 to $130 \mathrm{~m}$ (Table 3).

During the initial subsidence, two cycles of steep/smooth slopes can be identified in the curves, which represent alternations of rapid and decelerated subsidence (Fig. 6). The first rapid subsidence phase spans approximately from the Tithonian to the Early Berriasian interval (from 150.8 to $142.3 \mathrm{My}$ ), whereas the second one ranges from approximately the Early Barremian to the Middle Albian interval (from 129 to 108.7 My) (Fig. 6).

Using Royden's graphical method, the initial and thermal subsidence values were used to estimate the heat flow in the basin area at the end of the syn-extensional phase. A heat flow value ranging from 60 to $65 \mathrm{~mW} / \mathrm{m}^{2}$ is determined (Table 3 ).

\subsection{Thermal history reconstruction}

The vitrinite reflectance, measured in the basin infill deposits, varies considerably throughout the basin (Fig. 5 and Table 4). The lowest values were measured in the southern sector of the basin (0.47-0.57\%Ro), whereas in the central and northern sectors of the basin, high to very high vitrinite reflectance was measured (from 2.0 to $4.6 \%$ Ro) (Fig. 5). In the latter sectors, an inversion of the typical depth/VR relation trend was frequently observed in sequences in contact with thick permeable sandstone accumulations (Urbión Gr, DS4, DS5, DS6 and DS7, and Oliván Gr, DS8) as well as in deposits located close to faults (Fig. 5 and Fig. 3). The reflectance gradually decreased with increasing distance to the sandstone bodies and faults.

To estimate the thermal conditions reached by the basin infill during its evolution, a 2D thermal model was reconstructed. As a boundary condition, the heat flow variation over time was defined, assuming the average value estimated by means of Royden's method (64 $\mathrm{mW} / \mathrm{m}^{2}$ ) as the maximum heat flow at the end of the extensional stage (108.7 My) (Fig. 7). An exponential decrease in heat flow was considered for the post-extensional stage. $A$ surface heat flow of $60 \mathrm{~mW} / \mathrm{m}^{2}$ was adopted (Fig. 7), taking into account the data from a commercial oil well located in the area (Fernández et al. 1998).

The thermal model results determined the temperature distribution throughout the restored section of the basin over time (Fig. 8). In agreement with the burial depth, the basin infill reached maximum temperatures in the central-northern sector of the basin, whereas temperatures decreased toward the borders. Maximum temperatures were reached at the end of the syn-extensional stage (108.7 My), coinciding with the peak of heat flow previously estimated.

This article is protected by copyright. All rights reserved. 
The comparison of the vitrinite reflectance vs. depth theoretical curves with the \%Ro measured (Fig. 9) showed that the model could be considered correct in the southern part of the transect (calibration-well 1) but not in the rest of the section, where the \%Ro values were generally far higher than the model prediction. Moreover, in the central part of the section (calibration-wells 2, 3 and 4), an inversion of the typical depth/VR relation trend in the DS3 deposits was observed (Fig. 9). In the northern part of the section (calibration-well 5), no specific \%Ro-with-depth trend was observed; high values were measured in both the upper and lower stratigraphic levels of DS7 (Fig. 9). In the northernmost part of the section (calibration-well 6), the measured \%Ro values were markedly higher than the theoretical value predicted by the model (Fig. 9).

Additional calibration runs were performed to achieve a better fit between the measured and predicted data. However, increasing the maximum heat flow at the end of the extensional phase, from $64 \mathrm{~mW} / \mathrm{m}^{2}$ to $80-100 \mathrm{~mW} / \mathrm{m}^{2}$ (a value representative of an active rift basin, e.g., Allen \& Allen, 2009), did not substantially improve the results (Fig. 9).

\section{DISCUSSION}

The most remarkable feature of the tectonic subsidence curves is the occurrence, during the syn-extensional stage, of alternating rapid and slow subsidence phases (Fig. 6, legend). The rapid subsidence phases can be related to relevant tectonic events affecting the Iberian Plate at that time. The first rapid phase (Tithonian-Early Berriasian) can correspond to the opening of the North-Atlantic domain, whereas the second (Early Barremian-Early Albian) can correspond to the rifting in the future Biscay domain (Mas et al., 1993; Salas et al., 2001; García-Senz and Salas, 2011).

Total subsidence curves (Fig. 6) show that during the first rapid subsidence phase (from 150.8 to $142.3 \mathrm{My}$ ), the largest accommodation space was created in the central sector of the basin (Castillejo, Poveda, Yanguas and Rollamienta wells), while in the second phase (from 129 to $108.7 \mathrm{My}$ ), the largest accommodation space was created in the northern sector of the basin (Lazaro, Enciso, Molino and Yanguas wells). This subsidence trend can be explained in terms of the northward migration of the depocenters of the syn-extensional units (Mas et al., 1993; Guimerà et al., 1995; Omodeo Salé et al., 2014), which indicates that the accommodation space was formed with a gradual lateral displacement to the north from the beginning to the end of the extensional phase (Fig. 6).

This article is protected by copyright. All rights reserved. 
The low range of values obtained from heat flow estimation $\left(60-65 \mathrm{~mW} / \mathrm{m}^{2}\right)$ indicate that there was no significant thermal anomaly associated with basin formation, according to what it is expected in a typical extensional regime of rift type (Allen \& Allen, 2009). The low thermal anomaly indicated a reduced thermal subsidence (from 110 to $130 \mathrm{~m}$ ) and, consequently, the deposition of reduced thickness post-extensional deposits. However, both inorganic proxies, collected in a previous work, as well as vitrinite reflectance data, obtained herein, indicate that very high thermal conditions were recorded in the central-northern sector of the basin. Therefore, considering the "cold" scenario indicated by the results of the heat flow estimation, the cause of the thermal anomalies recorded in parts of the basin remains unclear. Analysis of the distribution of the depth-vitrinite reflectance relation in the basin deposits (Fig. 5) and comparison of the \%Ro with the thermal conditions estimated by the thermal model (Fig. 9) can help to clarify this issue.

VR indicate that, assuming a heat flow peak of $64 \mathrm{~mW} / \mathrm{m}^{2}$ at the end of the extensional stage, the model results were only correct for the southern sector of the basin, whereas in the central and northern sectors of the basin, the \%Ro values generally exceeded the model predictions (Fig. 9) and the typical depth-VR relation was inverted in some cases (calibrationwells 2,3 and 4 of Fig. 9). The anomalous distribution of the vitrinite reflectance cannot be explained by increasing burial (and subsequent deeper erosion) or by assuming a higher heat flow (regional metamorphism, as suggested by Mata et al., 2001; Del Río et al., 2009; Casas et al., 2012) because this would only result in an increase of the vitrinite reflectance with depth. Furthermore, according to Teichmüller \& Teichmüller (1982) and Taylor et al., (1998), such high vitrinite reflectance values $(\%$ Ro $>3$ ) are unlikely to be reached by simple burial, and an extra heating input into the basin needs to be considered. Anomalous vitrinite reflectance values can be caused by deep-lying magmatic bodies and/or dike intrusions (e.g., Alston Block, north-eastern England; Creaney, 1980; Illinois Basin, Stewart et al., 2005), magmatic activity associated with the evolution of the basin (e.g., Pannonian and Styrian Basins, Sachsenhofer, 1994; Yalcin et al., 1997) or salt diapirism and/or the presence of thick evaporitic units (e.g., Adana Basin, Yalcin et al., 1997; Lower Saxony Basin, Adriasola Muñoz et al., 2007). However, in the case of the Cameros Basin, none of these phenomena seems to apply.

A plausible explanation for the anomalous temperatures and temperature distribution observed in the Cameros Basin is the circulation of hot fluids. These fluids would have heated the sediments, regardless of their stratigraphic position, to temperatures higher than those expected in a normal extensional process. In such a case, the permeability of the sediments and the presence of faults/fractures are the most important factors determining the

This article is protected by copyright. All rights reserved. 
occurrence and distribution of anomalous temperatures. In the northernmost part of the basin, the original high permeability of the sandstones of Oliván Gr deposits (DS8) would favor the circulation of hot fluids, resulting in high temperatures in shallowly buried layers (Fig. 3, Fig. 9: calibration-well 6). Moreover, because this unit is located near the northern border of the basin, the circulation of hot fluids could be facilitated by the numerous faults affecting this area (Figs. 1 and 3). In DS7, located in the northern sector of the basin, numerous sandstone bodies intercalated with shale and limestone deposits could also facilitate hot fluid circulation, leading to higher temperatures along the whole stratigraphic succession (Fig. 9: calibration-well 5). The anomalous values recorded along DS3, characterized by an increase in the \%Ro values toward the top (Fig. 9: calibration-well 2, 3 and 4), could be attributed to the presence of a thick sandstone succession immediately overlying the DS3 unit (Fig. 5). This succession corresponds to the Urbión Gr, whose high permeability also facilitated the circulation of hot fluids. Finally, anomalously high temperatures are recorded in the deposits located close to the NW-SE trending postsedimentary faults (Fig. 1, Fig. 9: calibration-well 2 and 3), along which hot fluids could favorably circulate.

The combination of vitrinite reflectance and fluid inclusion data confirms that hot fluids circulated during the post-diagenetic stage in the central and northern sector of the basin. In the central part of the basin, Th for primary fluid inclusions $\left(120{ }^{\circ} \mathrm{C}\right.$, González-Acebrón, 2013), trapped in quartz overgrowths in sandstone of the Huerteles Fm (DS3, site FI-1 in Fig. 10 and Table 5), are in agreement with the temperatures predicted by the model for this sector (Fig. 10). However, the high VR determined in the same area (2.0-3.0\%Ro; see Fig. 9: calibration-well 2 and Table 4) indicates that the temperature increased in the postdiagenetic stage. In the northern sector of the basin, the Th for primary fluid inclusions, measured in quartz filling tension fractures in sandstones of the Urbión Gr (DS4; $290{ }^{\circ} \mathrm{C}$, González-Acebrón, 2013), indicate that the circulating fluids in this area were at considerably higher temperatures than those expected by burial only (site FI-2 in Fig. 10 and Table 5). Mata et al. (2001) reported similar Th for this area. These data agree with the high VR (up to $3.0 \%$ Ro) measured in the samples from this area (Fig. 9: calibration-well 4 and Table 4).

The circulation of hot fluids has to be causally related to the two metamorphic events recognized in the Cameros Basin. This appears to confirm a hydrothermal origin, as supported by Casquet et al. (1992), Alonso-Azcárate et al. (1999), Mas et al. (2003), Ochoa et al. (2007) and González-Acebrón et al. (2011, 2012). In the case of the Early-Middle Eocene in the age metamorphic event, hydrothermal hot fluids could be released from lower

This article is protected by copyright. All rights reserved. 
crustal melting during orogenesis, and fault systems serve as conduits. In contrast, the origin of the mid-early Late Cretaceous hydrothermal metamorphic event has not yet been clarified.

In the Lower to Upper Cretaceous times, the phenomena of magmatism, metamorphism and remagnetization have been recorded in different regions of NE Iberia (BasqueCantabrian range, Northern Pyrenees and Maestrat Basin in the Iberian Chain), as reviewed by Salas et al. (2005). The origin of this widespread thermal anomaly has not yet been investigated in detail, although there are hypotheses linking it to Bay of Biscay opening (e.g., Salas et al., 2005; Vegas et al., 1996). In the northern Pyrenees and Basque-Cantabrian domains, metamorphism has been dated as Albian in age and it has been related to the hyper-extension of the lithosphere and denudation of the mantle during the extensional regime (Lagabrielle et al., 2010). In contrast, the low thermal anomaly estimated in this work for the Cameros Basin area at the end of the extensional phase, indicates a reduced lithosphere thinning. For the Cameros Basin therefore, a major unsolved and controversial issue is how hot fluids could have reached the basin infill during the early-post-extensional stage. Future studies on the origin and flowpaths of the metamorphic hot fluids, integrated with the broader regional geological context, would significantly improve the understanding of the geodynamic evolution of the basin area during the Iberian Mesozoic extensional regime.

\section{CONCLUSIONS}

This study is an attempt to reconstruct the subsidence and thermal history of the Cameros Basin. Despite the uncertainties associated with the totally inverted and partially eroded state of the basin, the outcomes of this work help clarify some relevant questions on the thermal evolution of the basin.

Initial subsidence occurred from approximately 150 to 110 My (Tithonian to Early Albian) and was followed by thermal subsidence until approximately the end of the Cretaceous. During the initial subsidence, two rapid subsidence phases (from 150.8 to 142.3 My for the first and from 129 to 108.7 My for the second) were recorded, which may be related to the opening of the North-Atlantic domain and to the rifting in the future Bay of Biscay domain. During the first phase of basin evolution, the largest accommodation space was created in the central sector of the basin, whereas in the second phase, it was created in the northern sector. This trend is consistent with a northward migration of the depocenters during the extension stage.

This article is protected by copyright. All rights reserved. 
Subsidence data indicate a minor thermal anomaly associated with the extension. A maximum heat flow of $60-65 \mathrm{~mW} / \mathrm{m}^{2}$ at the end of the syn-extensional stage was estimated. The inferred "cold" extensional regime is not easily compatible with the high temperatures (very low to low grade metamorphism) recorded in the basin during the early postextensional and inversion stages, as indicated by several inorganic proxies and vitrinite reflectance data.

In terms of the cause of the observed thermal anomaly, the very high \%Ro values measured in the uppermost stratigraphic levels, computed deviations from the typical depth/VR relation and FI data suggest that there was circulation of hot fluids in the deposits during the evolution of the basin. Hot fluids heated the sediments, regardless of their stratigraphic position, to temperatures higher than those expected in an extensional regime of rift type. The permeability of the sediments and presence of fractures were the most important factors responsible for the anomalous temperature distribution. These results seem to confirm the hydrothermal nature of the metamorphic events that affected the basin. Compressional faults can be preferential conduits for hot fluid circulation during the Cenozoic metamorphic event. However, the origin and flowpaths of hot fluids during the postextensional metamorphism are still controversial and merit further study.

\section{Acknowledgments}

Funding for this research was provided by Spanish Government projects CGL200801648/BTE, CGL2008-04916/BTE, CGL2011-22709, and the Consolider-Ingenio 2010 programme, under CSD 2006-0004 "Topo-Iberia", by the UCM-CM (Universidad Complutense Madrid Community) and by the INCAR-CSIC - Oviedo. We thank Dr. Wolf Rottke (IES, Aachen), who provided all help necessary to successfully run the PetroMod at UCM. We also thank Dr. Laura González-Acebrón for helping us interpret the fluid inclusion data and an anonymous reviewer from the UCM for collaborating to realize a clear and comprehensible final version of this work. The article benefited from reviews and commentary from Prof. Antonio Casas, Prof. François Roure and Prof. Cynthia Ebinger, who greatly improved the quality of the manuscript.

\section{References}

Adriasola MuÑOz, Y., LitTKE, R. \& BRIX, M.R. (2007) Fluid Systems and Basin Evolution of the Western Lower Saxony Basin, Germany. Geofluids, 7, 335-355.

Alonso-Azcárate, J., BARRenecheA, J.F., MAS, J.R. \& RodAs, M. (1999) Factores Que Controlan La Evolución De Los Parámetros Cristaloquímicos Y Asociaciones Minerales En Las Rocas

This article is protected by copyright. All rights reserved. 
Sedimentarias Del Grupo Enciso (Cretácio Inferior). Cuenca De Cameros, La Rioja (Norte De España). Revista de la Sociedad Geológica de España, 12, 439-451.

Alonso, A. \& MAS, J.R. (1993) Control Tectónico E Influencia Del Eustatismo En La Sedimentación Del Cretácico Inferior De La Cuenca De Los Cameros. Cuadernos de Geología Ibérica, 17, 285-310.

Alonso, Á., Floquet, M., Mas, R. \& Meléndez, A. (1993) Late Cretaceous Carbonate Platforms: Origin and Evolution, Iberian Range, Spain. In: Cretaceous Carbonate Platforms (Ed. by R. W. Scott, J. A. T. Simo \& J. P. Masse), American Association of Petroleum Geologists, Memoir, 56, 297-313, Oklahoma.

Allen, P.A. \& Allen, J.R. (2009) Basin Analysis: Principles and Applications. Blackwell.

ARCHE, A. \& LóPEZ-GómeZ, J. (1996) Origin of the Permian-Triassic Iberian Basin, Central-Eastern Spain, Elsevier. 266, 443-464.

BARRENECHEA, J.F., RoDAS, M. \& MAS, J.R. (1995) Clay Mineral Variations Associated with Diagenesis and Low-Grade Metamorphism of Early Cretaceous Sediments in the Cameros Basin, Spain. Clay Minerals, 30, 119-133.

Barrenechea, J.F., Rodas, M., Frey, M., Alonso-AzcÁrate, J. \& MAS, J.R. (2001) Clay Diagenesis and Low-Grade Metamorphism of Tithonian and Berriasian Sediments in the Cameros Basin (Spain). Clay Minerals, 36, 325-333.

Baur, F., Wielens, H. \& LitTKe, R. (2009) Basin and Petroleum Systems Modeling at the Jeanne D'arc and Carson Basin Offshore Newfoundland, Canada. Focus.

BRENNER, P. (1976) Ostracoden Und Charophyten Des Spanischen Wealden (Systematik, Ökologie, Stratigraphie, Paläogeographie). Palaeontographica Abteilung A: PalaeozoologieStratigraphie, 152, 113-201.

BÜKER, C., LITTKE, R. \& WELTE, D.H. (1995) 2d-Modelling of the Thermal Evolution of Carboniferous and Devonian Sedimentary Rocks of the Eastern Ruhr Basin and Northern Rhenish Massif, Germany. Zeitschrift der Deutschen Geologischen Gesellschaft, 146, 321-339.

CASAS-SAINZ, A.M. (1992) El Frente Norte de las Sierras de Cameros: Estructuras Cabalgantes Y Campo De Esfuerzos. Zubía Monográfico, 4, 1-220.

CASAS-SAINZ, A.M. \& GIL-IMAZ, A. (1998) Extensional Subsidence, Contractional Folding and Thrust Inversion of the Eastern Cameros Basin, Northern Spain. Geologische Rundschau, 86, 802818.

Casas, A., Río, P., Mata, P., Villalain, J. \& Barbero, L. (2012) Comment on González-Acebrón Et Al. Criteria for the Recognition of Localization and Timing of Multiple Events of Hydrothermal Alteration in Sandstones Illustrated by Petrographic, Fluid Inclusion, and Isotopic Analysis of the Tera Group, Northern Spain Int J Earth Sciences (2011) 100:1811-1826. International Journal of Earth Sciences, 101, 2043-2048.

Casquet, C., Galindo, C., González-Casado, J.M., Alonso, A., Mas, R., Rodas, M., García, E. \& BARRENECHEA, J.F. (1992) El Metamorfismo en la cuenca de Los Cameros. Geocronología e implicaciones tectónicas. Geogaceta, 11, 22-25.

This article is protected by copyright. All rights reserved. 
Creaney, S. (1980). Petrographic Texture and Vitrinite Reflectance Variation on the Alston Block, North-East England. Proceedings of the Yorkshire Geological and Polytechnic Society, Geological Society of London.

Del Río, P., Barbero, L., Mata, P. \& Fanning, C.M. (2009) Timing of Diagenesis and Very Low-Grade Metamorphism in the Eastern Sector of the Sierra De Cameros (Iberian Range, Spain): A UPb Shrimp Study on Monazite. Terra Nova, 21, 438-445.

FERNÁNDEZ, M., MARZÁN, I., CORREIA, A. \& RAMALHO, E. (1998) Heat Flow, Heat Production, and Lithospheric Thermal Regime in the Iberian Peninsula. Tectonophysics, 291, 29-53.

GARCíA, A. \& MAS, R. (2004) Segunda Fase De Post-Rifting:Cretácico Superior. In: Geología De España (Ed. by Vera, J. A.), 510-522. Sociedad Geológica de España; Instituto Geológico y Minero de España, Madrid.

García-SenZ, J. \& Salas, R. (2011) Sedimentary Response to Continental Rifting in Iberia. Keynote in 28th Meeting of Sedimentology 2011, Zaragoza, Spain, 87.

GOLBERG, J.M., GUIRAUD, M., MALUSKY, H. \& SEGURET, M. (1988) Caractères Pétrologiques Et Âge Du Métamorphisme En Contexte Distensif Du Bassin Sur Décrochement De Soria (Crétacé Inférieur, Nord Espagne). Comptes Rendus de l'Academia des Sciences de Paris, 307, 521-527.

Goldstein, R.H. \& ReYNOLDS, T.J. (1994) Systematics of Fluid Inclusions in Diagenetic Minerals. SEPM (Society for Sedimentary Geology) Short Course, 31, 199.

González-Acebrón, L., Goldstein, R.H., MAS, R. \& ARRIBAS, J. (2011) Criteria for Recognition of Localization and Timing of Multiple Events of Hydrothermal Alteration in Sandstones Illustrated by Petrographic, Fluid Inclusion, and Isotopic Analysis of the Tera Group, Northern Spain. International Journal of Earth Sciences, 100, 1811-1826.

GonzÁlez-Acebrón, L., Goldstein, R., MAS, R. \& ArRibas, J. (2012) Answer to the Comment of Casas et al. about González Acebrón et al.'s (2011) paper. International Journal of Earth Sciences, 101(7), 2049-2053.

GonzÁlez-Acebrón, L., Omodeo-Salé, S., lóPez-Elorza, M., Mas, R., ArRiBAs, J., Goldstein, R.H. (2013) Comparison between a Basin Thermal Model Based on Vitrinite Reflectance with Fluid Inclusion Microthermometry: Cameros Basin, N Spain. ECROFI XXII. Instanbul, Turkey, 5556.

Gradstein, F.M., OGG, J.G. \& SMITH, A.G. (2004) A Geologic Time Scale 2004. Cambridge University Press.

Guimera, J. \& Alvaro, M. (1990) Structure et evolution de la compression alpine dans la Chaîne Ibérique et la Chaîne Côtière Catalane (Espagne), Bull. Soc. Géol. Fr. 8, 339-348.

GuimerÀ, J., Alonso, Á. \& MAS, J.R. (1995) Inversion of an Extensional-Ramp Basin by a Newly Formed Thrust: The Cameros Basin (N. Spain). In: Basin Inversion (Ed. by J. G. Buchanan \& P. G. Buchanan), Geological Society, London, Special Publications, 88, 433-453.

GuiraUd, M. \& SÉGURET, M. (1985) A Releasing Solitary Overstep Model for the Late Jurassic-Early Cretaceous (Wealdian) Soria Strike-Slip Basin (Northern Spain). In: Strike Slip Deformation,

This article is protected by copyright. All rights reserved. 
Basin Formation and Sedimentation (Ed. by K. T. Biddle \& N. Christie-Blick), Sepm Special Publication, 37, 159-175. Society of Economic Paleontologists and Mineralogists, Tulsa.

hammond, J., Kendall, J.-M., Stuart, G., Ebinger, C., Bastow, I., Keir, D., Ayele, A., Belachew, M., GoItom, B. \& OgubazGHI, G. (2013) Mantle Upwelling and Initiation of Rift Segmentation beneath the Afar Depression. Geology, 41, 635-638.

ICCP (1998) The New Vitrinite Classification (Iccp System 1994). Fuel, 77, 349-358.

ICCP (2001) The New Inertinite Classification (Iccp System 1994). Fuel, 80, 459-471.

ISO-7404-2 (2009) Methods for the Petrographic Analysis of Coals - Part 2: Methods of Preparing Coal Samples. International Organization for Standardization Geneva, Switzerland., 12 pp.

ISO-7404-5 (2009) Methods for the Petrographic Analysis of Coal-Part 5: Methods of Determining Microscopically the Reflectance of Vitrinite. International Organization for Standardization, Geneva, switzerland, 14 pp.

Jammes, S., LAVIeR, L. \& MANATSChaL, G. (2010) Extreme crustal thinning in the Bay of Biscay and the Western Pyrenees: From observations to modeling. Geochemistry Geophysics Geosystems, V. 11

Lagabrielle, Y., Labaume, P., And De Saint Blanquat, M. (2010). Mantle exhumation, crustal denudation, and gravity tectonics during Cretaceous rifting in the Pyrenean realm (SW Europe): Insights from the geological setting of the Iherzolite bodies. Tectonics, 29 (4), DOI: 10.1029/2009TC002588.

Leischner, K., Welte, D. \& LitTKE, R. (1993) Fluid Inclusions and Organic Maturity Parameters as Calibration Tools in Basin Modelling. In: Basin modelling, Advances and Applications (Ed.by A. G. Doré, J. H. Augustson, C. Hermanrud, D. J. Steward, \& O. Sylta), NPF Special Publications, 3, 161-172.

Mantilla-Figueroa, L.C., Casquet, C. \& MAS, J.R. (1998) Los Paleofluidos En El Grupo Oncala, Cuenca De Cameros (La Rioja, España): Datos De Inclusiones Fluidas, Isótopos De Oxígeno Y Sem. Geogaceta, 24, 207-210.

Mantilla-FigueroA, L.C., Casquet, C. \& MAS, J.M. (1999) Consideraciones Geoquímicas Y De Procedencia, Entorno a La Ocurrencia De Allanitas En El Anticlinal Del Pégado (Cuenca De Cameros, España). Boletín de la Sociedad Española de Mineralogía, 22A, 67-68.

MAntilla-FIGUeroA, L.C. (2002) Determinación De Paleotemperaturas En La Cuenca Cretácica De Cameros (La Rioja, España), a Partir Del Estudio De Cloritas. Boletín de Geología (Bucaramanga), 24, 19-27.

Martín-Closas, C. \& Alonso-Millán, Á. (1998) Estratigrafía Y Bioestratigrafía (Charophyta) Del Cretácico Inferior En El Sector Occidental De La Cuenca De Cameros (Cordillera Ibérica). Revista de la Sociedad Geológica de España, 11, 253-269.

Mas, R., Alonso, Á. \& Guimerì, J. (1993) Evolución Tectonosedimentaria De Una Cuenca Extensional Intraplaca: La Cuenca Finijurásica-Eocretácica De Los Cameros (La Rioja-Soria). Revista de la Sociedad Geológica de España, 6, 129-144.

This article is protected by copyright. All rights reserved. 
mas, R., Benito, M.ı., Arribas, J., Serrrano, A., Guimerà, J., Alonso, Á. \& Alonso-Azcárate, J. (2002) La Cuenca de Cameros: desde la extensión finijurásica-eocretácica a la inversión terciaria - Implicaciones en la exploración de hidrocarburos. Zubía Monográfico, 14, 9-64.

mas, R., Benito, M.l., Arribas, J., Serrano, A., Guimerà, J., Alonso, Á. \& Alonso-Azcárate, J. (2003) Geological Field Trip 11-the Cameros Basin: From Late Jurassic-Early Cretaceous extension to Tertiary contractional inversion: Implications of hydrocarbon exploration. AAPG International Conference and Exhibition, Total. Barcelona (Spain), 1-52.

mas, R., Benito, M.I., Arribas, J., Alonso, A., Arribas, M.E., González-Acebrón, L., Hernán, J., QuiJADA, E., SuÁREZ, P. \& OMODEO-SALÉ, S. (2011) Evolution of an Intra-Plate Rift Basin: The Latest Jurassic-Early Cretaceous Cameros Basin (Northwest Iberian Ranges, North Spain). Post-Meeting field trips 28th IAS Meeting, Zaragoza (Spain). (Ed. by Arenas, C., Pomar, L. and Colombo, F.). Geoguías 8, 117-154.

Mata, M.P., Casas, A.M., Canals, A., GIL, A. \& Pocoví, A. (2001) Thermal History During Mesozoic Extension and Tertiary Uplift in the Cameros Basin, Northern Spain. Basin Research, 13, 91111.

Muñoz, A., Soria, A., Canudo, J.I., Casas, A.M., Gil, A. \& MatA, M.P. (1997) Caracterización estratigráfica y sedimentológica del Albiense marino del borde Norte de la Sierra de Cameros. Implicaciones paleogeográficas. Cuadernos de Geología Ibérica, 22, 139-163.

OchoA, M., ARRibas, M.E., ARRiBAS, J. \& MAS, R. (2007) Significance of Geochemical Signatures on Provenance in Intracratonic Rift Basins: Examples from the Iberian Plate. In: Sedimentary Provenance and Petrogenesis: Perspectives from Petrography and Geochemistry (Ed. by J. Arribas, M. J. Johnsson and S. Critelli), Geological Society of America Special Papers, 420, 199-219.

OGG, J.G., OGG, G. \& GradsteIn, F.M. (2008) The Concise Geologic Time Scale. Elsevier.

Omodeo Salé, S., GuimerÀ, J., MAS, R. \& ArRiBas, J. (2014) Tecono-Stratigraphic Evolution of an Inverted Extensional Basin: The Cameros Basin (North of Spain). . International Journal of Earth Sciences, 103 (6), 1597-1620, DOI 10.1007/s00531-014-1026-5.

PlatT, N.H. (1989) Continental Sedimentation in an Evolving Rift Basin: The Lower Cretaceous of the Western Cameros Basin (Northern Spain). Sedimentary Geology, 64, 91-109.

Poelchau, H., Baker, D., Hantschel, T., Horsfield, B. \& Wygrala, B. (1997) Basin Simulation and the Design of the Conceptual Basin Model. In: Petroleum and Basin Evolution (Ed. by D. Welte, B. Horsfield, \& D. Baker ), Springer, Berlin: 3-70.

Royden, L. \& Keen, C. (1980) Rifting Process and Thermal Evolution of the Continental Margin of Eastern Canada Determined from Subsidence Curves. Earth and Planetary Science Letters, 51, 343-361.

Royden, L. (1986) A Simple Method for Analyzing Subsidence and Heat Flow in Extensional Basins. In: Thermal Modeling in Sedimentary Basins (Ed. by Burrus, Technip, Paris: 49-73.

SACHSENHOFER, R.F. (1994) Petroleum Generation and Migration in the Styrian Basin (Pannonian Basin System, Austria): An Integrated Geochemical and Numerical Modelling Study. Marine and Petroleum Geology, 11, 684-701.

This article is protected by copyright. All rights reserved. 
Salas, R. \& CASAS, A. (1993) Mesozoic Extensional Tectonics, Stratigraphy and Crustal Evolution During the Alpine Cycle of the Eastern Iberian Basin. Tectonophysics, 228, 33-55.

Salas, R., Guimerì, J., Mas, R., Martín-Closas, C., Meléndez, A. \& Alonso, Á. (2001) Evolution of the Mesozoic Central Iberian Rift System and Its Cainozoic Inversion (Iberian Chain). PeriTethys Memoir 2001, vol. 6, 145-186.

SALAS, R., CAJA, M., MAS, R., MARTÍN-MARTíN, J. \& PERMANYER, A. (2005) Mid-Late Cretaceous Volcanism, Metamorphism and the Regional Thermal Event Affecting the Northeastern Iberian Basins (Spain). Global Events during the Quiet Aptian-Turonian Superchron. Geologie Alpine, Série Spéciale, 6, 55-59.

SALOMON, J. (1982) Les formations continentales du bassin de Soria (Sierra De Los Cameros) au Cretace inferieur: relation entre tectonique et sedimentation. Segundo Coloquio de Estratigrafía y Paleogeografía del Cretácico de España, Grupo Espanol del Mesozoico. Resúmenes de las Comunicaciones, 14.

Sclater, J.G. \& Christie, P. (1980) Continental Stretching: An Explanation of the Post-MidCretaceous Subsidence of the Central North Sea Basin. Journal of Geophysical Research: Solid Earth, 85, 3711-3739.

SCHMOKER, J.W. \& HALLEY, R.B. (1982) Carbonate Porosity Versus Depth; a Predictable Relation for South Florida. AAPG Bulletin, 66, 2561-2570.

SCHUDACK, M. (1987) Charophytenflora Und Fazielle Entwicklung Der Grenzschichten Mariner Jura/Wealden in Den Nordwestlichen Iberischen Ketten (Mit Vergleichen Zu Asturien Und Kantabrien). Palaeontographica Beiträge zur Naturgeschichte der Vorzeit Abteilung B, 204, 1180.

Simancas, J., Carbonell, R., González lodeiro, F., Pérez Estaún, A., Juhlin, C., Ayarza, P., Kashubin, A., Azor, A., Martínez Poyatos, D. \& Almodovar, G.R. (2003) Crustal Structure of the Transpressional Variscan Orogen of Sw Iberia: Sw Iberia Deep Seismic Reflection Profile (Iberseis). Tectonics, 22.

Stewart, A., Massey, M., Padgett, P., Rimmer, S. \& Hower, J. (2005) Influence of a Basic Intrusion on the Vitrinite Reflectance and Chemistry of the Springfield (No. 5) Coal, Harrisburg, Illinois. International Journal of Coal Geology, 63, 58-67.

Suarez-Gonzalez, P., QuiJadA, I.E., Benito, M.I. \& MAS, R. (2013) Eustatic Versus Tectonic Control in an Intraplate Rift Basin (Leza Fm, Cameros Basin). Chronostratigraphic and Paleogeographic Implications for the Aptian of Iberia. Journal of Iberian Geology, 39, 285312.

SWEenEY, J.J. \& BuRnham, A.K. (1990) Evaluation of a Simple Model of Vitrinite Reflectance Based on Chemical Kinetics (1). AAPG Bulletin, 74, 1559-1570.

Taylor, G., Teichmüler, M., Davis, A., Diessel, C., Littke, R. \& Robert, P. (1998) Organic Petrology: Gebrüder Borntraeger, Berlin.

TeICHMÜLleR, M. \& TeICHMÜLleR, R. (1982) Fundamentals of Coal Petrology. In: Stach's Textbook of Coal Petrology (ed. by E. Stach, M.-Th.Mackowsky, M. Teichmüller, G.H., Taylor, D.

This article is protected by copyright. All rights reserved. 
Chandra, \& R. Techmüller), 3rd revised and enlarged edition: Gebrüder Borntraeger, Berlin, Stuttgart, 5-86.

Tissot, B., Pelet, R. \& Ungerer, P. (1987) Thermal History of Sedimentary Basins, Maturation Indices, and Kinetics of Oil and Gas Generation. AAPG Bull.; (United States), 71 (12), 14451466.

Tugend, J., Manatschall, G., \& KusniR, N. J. (2015). Spatial and temporal evolution of hyperextended rift systems: Implication for the nature, kinematics, and timing of the IberianEuropean plate boundary. Geology, 43 (1), 15-18.

Van Wees, J., Van Bergen, F., David, P., Nepveu, M., Beekman, F., Cloetingh, S. \& Bonté, D. (2009) Probabilistic Tectonic Heat Flow Modeling for Basin Maturation: Assessment Method and Applications. Marine and Petroleum Geology, 26, 536-551.

VEGAS, R., JUAREZ, M.T. \& KÄLIN, O. (1996). Tectonic And geodinamic significance of paleomagnetic rotation in the Iberian chain, Spain. Geogaceta, 19, 11-12

VERA, J.-A. (2001) Evolution of the South Iberian Continental Margin. Mémoires du Muséum national d'histoire naturelle, 186, 109-143.

Verges, J. \& Garcia-Senz, J. (2001) Mesozoic Evolution and Cenozoic Inversion of the Pyrenean Rift. Mémoires du Muséum national d'histoire naturelle, 186, 187-212.

WALTHAM, D. (2001) Decompact. Royal Holloway (UK).

WATTS, A. \& RYAN, W. (1976) Flexure of the Lithosphere and Continental Margin Basins. Tectonophysics, 36, 25-44.

Yalcin, M., LitTKe, R. \& SACHSEnHOfeR, R. (1997) Thermal History of Sedimentary Basins. In: Petroleum and Basin Evolution (Ed. by D. Welte, B. Horsfield, \& D. Baker), 71-167. Springer.

\section{Figure captions}

Fig. 1.- Location and geological setting of the Cameros Basin and location of the samples used for vitrinite reflectance and fluid inclusion measurements. A-A' indicates the trace of the cross-section of Fig. 3.

Fig. 2.- Chrono-stratigraphic sketch of the Cameros basin infill and distribution of the synextensional depositional sequences (DS) and relative lithological units (Groups and Formations) (Modified from Mas et al., 2003). The stratigraphic location of samples collected for vitrinite reflectance (VR) and fluid inclusion (FI) measurements are also indicated. The situation of the samples, at depth, is indicated in Fig. 3.

Fig. 3.- Balanced geological cross-section (a) and restored section (b) used in the basic geological model (from Omodeo Salé et al., 2014). (a) The location and stratigraphic position of the samples used for vitrinite reflectance and fluid inclusions measurements. (b) The situation of virtual wells used for subsidence and heat flow calculations. The trace of the cross-section is indicated in Fig. 1.

Fig. 4.- Main geological parameters of the virtual wells plotted onto the restored crosssection. For every unit considered, the age (My), thickness ( $m)$ and lithology (\%) are

This article is protected by copyright. All rights reserved. 
indicated. Thk = thickness; Lithol = lithology; Lm = limestone; Sn = sandstone; and Sh = shale.

Fig. 5.- Restored section of the Cameros Basin displaying the sedimentary units and architecture. The samples used for \%Ro and fluid inclusion analysis are depicted at the original paleo-depth. The location of the samples at the present-day is indicated in Fig. 3. To calibrate the $2 \mathrm{D}$ thermal model, the measured \%Ro values were grouped and projected onto six calibration wells that were arranged along the section. The mean \%Ro measured for each sample is indicated.

Fig. 6.- Total (blue) and tectonic (pink) subsidence curves obtained for each well. The following two types of tectonic subsidence were recognized during the syn-extensional stage: rapid and decelerated subsidence.

Fig. 7.- Curve of heat flow variation through = time for the Cameros Basin. An average value of $64 \mathrm{~mW} / \mathrm{m}^{2}$, estimated with Royden's method, is considered at the end of the synextensional stage (108.7 My).

Fig. 8.- 2D thermal models acquired for several time slices with the PetroMod program.

Fig. 9.- Calibration with the vitrinite reflectance data of the 2D thermal models depicted in Fig. 10. Two calibrations were performed. The solid curve refers to the maximum heat flow estimate according to the method of Royden (1986), whereas the dotted curve refers to a maximum heat flow of $100 \mathrm{~mW} / \mathrm{m}^{2}$. In both cases, the calibration was not satisfactory.

Fig. 10.- Time/temperature/depth plots extracted from the 2D thermal model at the site of the Fl-1 and Fl-2 fluid inclusion samples (Fig. 5). Fl-1 and $\mathrm{Fl}-12$ samples were situated at their stratigraphic places.

\section{Tables}

Table 1.- Ages of the basin infill units and their lithological composition as a percentage of the three main lithologies (limestone, sandstone, and shale). These units were considered in the subsidence calculations and in the 2D thermal model input.

Table 2.- Thickness, heterolitic lithologies, $\Phi$ (porosity) and parameter c (compaction factor) values attributed to different units of each well.

Table 3.- Values of the initial and thermal subsidence interpreted from the tectonic subsidence curves for each virtual well. Values of the heat flow $\left(\mathrm{mW} / \mathrm{m}^{2}\right)$, estimated with Royden's graphical method, are also indicated.

Table 4 The vitrinite reflectance measured for each sample.

Table 5 Fluid inclusion data (from González-Acebrón et al., 2013) used to calibrate the 2D thermal models.

This article is protected by copyright. All rights reserved. 


\begin{tabular}{|c|c|c|c|c|c|c|}
\hline \multicolumn{2}{|c|}{ Age (My) } & \multirow{2}{*}{ Unit } & \multirow{2}{*}{ Group/Formation } & \multicolumn{3}{|c|}{ Lithology } \\
\hline From & To & & & Limestone & Sandstone & Shale \\
\hline 65.5 & 98 & & Upper Cretaceous & 60 & 20 & 20 \\
\hline 98 & 106.5 & Post-ext. & Utrillas Fm & 0 & 80 & 20 \\
\hline 121 & 108.7 & DS8 & Olivan $\mathrm{Gr}$ & 5 & 70 & 25 \\
\hline \multirow{4}{*}{127} & \multirow{4}{*}{121} & \multirow{4}{*}{ DS7 } & Leza Fm & - & - & - \\
\hline & & & Enciso Gr & 45 & 20 & 35 \\
\hline & & & Urbión Gr & 0 & 60 & 40 \\
\hline & & & Abejar Fm & 0 & 70 & 30 \\
\hline \multirow{2}{*}{129} & \multirow{2}{*}{127} & \multirow{2}{*}{ DS6 } & Urbión Gr & 0 & 60 & 40 \\
\hline & & & Pantano Fm & 0 & 80 & 20 \\
\hline \multirow{2}{*}{136.7} & \multirow{2}{*}{129} & \multirow{2}{*}{ DS5 } & Urbión Gr & 0 & 60 & 40 \\
\hline & & & Golmayo Fm & 40 & 40 & 20 \\
\hline 142.3 & 136.7 & DS4 & Urbión Gr & 0 & 60 & 40 \\
\hline \multirow{2}{*}{145.5} & \multirow{2}{*}{142.3} & \multirow{2}{*}{ DS3 } & Valdeprado Fm & 60 & 4 & 36 \\
\hline & & & Huerteles Fm & 15 & 35 & 50 \\
\hline 150.8 & 145.5 & $\mathrm{DS} 1+2$ & Tera Gr & 5 & 60 & 35 \\
\hline 164.7 & 150.8 & Pre-ext. & Marine Jurassic & 100 & 0 & 0 \\
\hline
\end{tabular}

\begin{tabular}{|c|c|c|c|c|c|c|}
\hline $\begin{array}{c}\text { Virtual } \\
\text { Wells/Units }\end{array}$ & $\begin{array}{l}\text { Thicknes } \\
\text { s }\end{array}$ & $\begin{array}{l}\text { Limeston } \\
\text { e }\end{array}$ & $\begin{array}{l}\text { Sandsto } \\
\text { ne }\end{array}$ & Shale & $\Phi$ & c \\
\hline \multicolumn{7}{|l|}{ Fuentetoba } \\
\hline Upper Cretaceous & 550 & 60 & 20 & 20 & 0.53 & $\begin{array}{l}0.0004 \\
68\end{array}$ \\
\hline Utrilla Fm & 100 & - & 80 & 20 & 0.518 & $\begin{array}{l}0.0003 \\
18\end{array}$ \\
\hline DS7 & 710 & - & 70 & 30 & 0.532 & $\begin{array}{l}0.0003 \\
42\end{array}$ \\
\hline DS6 & 1006 & - & 80 & 20 & 0.518 & $\begin{array}{l}0.0003 \\
18\end{array}$ \\
\hline DS5 & 713 & 20 & 40 & 40 & 0.55 & $\begin{array}{l}0.0004 \\
16\end{array}$ \\
\hline $\mathrm{DS} 1+2$ & 306 & 25 & 40 & 35 & 0.544 & $\begin{array}{l}0.0004 \\
165 \\
\end{array}$ \\
\hline \multicolumn{7}{|l|}{ Rollamienta } \\
\hline Upper Cretaceous & 550 & 60 & 20 & 20 & 0.53 & $\begin{array}{l}0.0004 \\
68\end{array}$ \\
\hline Utrilla Fm & 100 & - & 80 & 20 & 0.518 & $\begin{array}{l}0.0003 \\
18\end{array}$ \\
\hline DS7 & 1158 & - & 70 & 30 & 0.532 & $\begin{array}{l}0.0003 \\
42\end{array}$ \\
\hline DS6 & 1612 & - & 80 & 20 & 0.518 & $\begin{array}{l}0.0003 \\
18\end{array}$ \\
\hline $\mathrm{DS} 1+2$ & 1194 & 30 & 35 & 30 & 0.5135 & $\begin{array}{l}0.0004 \\
035\end{array}$ \\
\hline \multicolumn{7}{|l|}{ Poveda } \\
\hline Upper Cretaceous & 550 & 60 & 20 & 20 & 0.53 & $\begin{array}{l}0.0004 \\
68\end{array}$ \\
\hline Utrilla Fm & 100 & - & 80 & 20 & 0.518 & $\begin{array}{c}0.0003 \\
18\end{array}$ \\
\hline
\end{tabular}

This article is protected by copyright. All rights reserved. 


\begin{tabular}{|c|c|c|c|c|c|c|}
\hline DS7 & 1232 & - & 60 & 40 & 0.546 & $\begin{array}{l}0.0003 \\
66\end{array}$ \\
\hline DS6 & 582 & - & 60 & 40 & 0.546 & $\begin{array}{l}0.0003 \\
66\end{array}$ \\
\hline DS3 & 1738 & 15 & 35 & 50 & 0.563 & $\begin{array}{l}0.0004 \\
275\end{array}$ \\
\hline $\mathrm{DS} 1+2$ & 1900 & 5 & 60 & 35 & 0.54 & $\begin{array}{l}0.0003 \\
665\end{array}$ \\
\hline \multicolumn{7}{|l|}{ Castillejo } \\
\hline Upper Cretaceous & 550 & 60 & 20 & 20 & 0.53 & $\begin{array}{l}0.0004 \\
68\end{array}$ \\
\hline Utrilla Fm & 100 & - & 80 & 20 & 0.518 & $\begin{array}{l}0.0003 \\
18\end{array}$ \\
\hline DS8 & 43 & 5 & 70 & 25 & 0.526 & $\begin{array}{l}0.0003 \\
425\end{array}$ \\
\hline DS7 & 1463 & 10 & 50 & 40 & 0.548 & $\begin{array}{l}0.0003 \\
91\end{array}$ \\
\hline DS6 & 542 & - & 60 & 40 & 0.546 & $\begin{array}{l}0.0003 \\
66\end{array}$ \\
\hline DS3 & 2456 & 30 & 25 & 45 & 0.559 & $\begin{array}{l}0.0004 \\
53\end{array}$ \\
\hline $\mathrm{DS} 1+2$ & 1079 & 5 & 60 & 35 & 0.54 & $\begin{array}{l}0.0003 \\
665 \\
\end{array}$ \\
\hline \multicolumn{7}{|l|}{ Yanguas } \\
\hline Upper Cretaceous & 550 & 60 & 20 & 20 & 0.53 & $\begin{array}{l}0.0004 \\
68\end{array}$ \\
\hline Utrilla Fm & 100 & - & 80 & 20 & 0.518 & $\begin{array}{l}0.0003 \\
18\end{array}$ \\
\hline DS8 & 920 & 5 & 70 & 25 & 0.526 & $\begin{array}{l}0.0003 \\
425\end{array}$ \\
\hline DS7 & 2480 & 20 & 40 & 40 & 0.55 & $\begin{array}{l}0.0004 \\
16\end{array}$ \\
\hline DS6 & 440 & - & 60 & 40 & 0.546 & $\begin{array}{l}0.0003 \\
66\end{array}$ \\
\hline DS5 & 220 & - & 60 & 40 & 0.546 & $\begin{array}{l}0.0003 \\
66\end{array}$ \\
\hline DS4 & 238 & - & 60 & 40 & 0.546 & $\begin{array}{l}0.0003 \\
66\end{array}$ \\
\hline DS3 & 1800 & 50 & 15 & 35 & 0.549 & $\begin{array}{l}0.0004 \\
79\end{array}$ \\
\hline \multicolumn{7}{|l|}{ Molino } \\
\hline Upper Cretaceous & 550 & 60 & 20 & 20 & 0.53 & $\begin{array}{l}0.0004 \\
68\end{array}$ \\
\hline Utrilla Fm & 100 & - & 80 & 20 & 0.518 & $\begin{array}{l}0.0003 \\
18\end{array}$ \\
\hline DS8 & 1468 & 5 & 70 & 25 & 0.526 & $\begin{array}{l}0.0003 \\
425\end{array}$ \\
\hline DS7 & 3246 & 35 & 30 & 35 & 0.546 & $\begin{array}{l}0.0004 \\
415\end{array}$ \\
\hline DS6 & 280 & - & 60 & 40 & 0.546 & $\begin{array}{l}0.0003 \\
66\end{array}$ \\
\hline DS5 & 135 & - & 60 & 40 & 0.546 & $\begin{array}{l}0.0003 \\
66\end{array}$ \\
\hline DS4 & 57 & - & 60 & 40 & 0.546 & $\begin{array}{l}0.0003 \\
66\end{array}$ \\
\hline DS3 & 131 & 50 & 15 & 35 & 0.549 & $\begin{array}{l}0.0004 \\
79 \\
\end{array}$ \\
\hline
\end{tabular}

This article is protected by copyright. All rights reserved. 


\begin{tabular}{|c|c|c|c|c|c|c|}
\hline Upper Cretaceous & 550 & 60 & 20 & 20 & 0.53 & $\begin{array}{l}0.0004 \\
68\end{array}$ \\
\hline Utrilla Fm & 100 & - & 80 & 20 & 0.518 & $\begin{array}{l}0.0003 \\
18\end{array}$ \\
\hline DS8 & 2090 & 5 & 70 & 25 & 0.526 & $\begin{array}{l}0.0003 \\
425\end{array}$ \\
\hline DS7 & 2300 & 40 & 25 & 35 & 0.547 & $\begin{array}{l}0.0004 \\
54\end{array}$ \\
\hline \multicolumn{7}{|l|}{ Lazaro } \\
\hline Upper Cretaceous & 550 & 60 & 20 & 20 & 0.53 & $\begin{array}{l}0.0004 \\
68\end{array}$ \\
\hline Utrilla Fm & 100 & - & 80 & 20 & 0.518 & $\begin{array}{l}0.0003 \\
18\end{array}$ \\
\hline DS8 & 2090 & 5 & 70 & 25 & 0.526 & $\begin{array}{l}0.0003 \\
425\end{array}$ \\
\hline DS7 & 3600 & 45 & 20 & 35 & 0.548 & $\begin{array}{l}0.0004 \\
665\end{array}$ \\
\hline
\end{tabular}

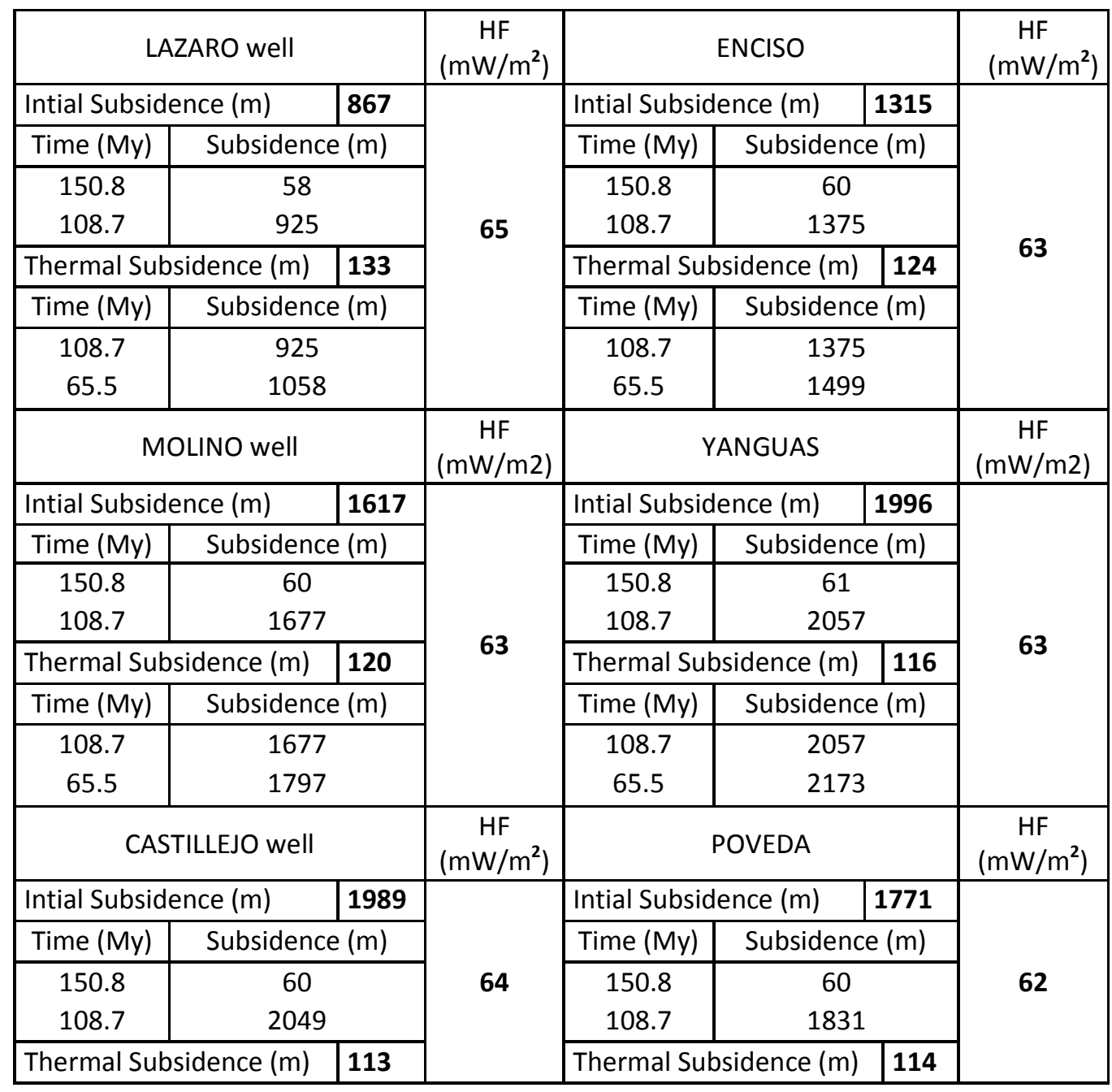

This article is protected by copyright. All rights reserved. 


\begin{tabular}{|c|c|c|c|c|c|c|c|}
\hline Time (My) & \multicolumn{2}{|c|}{ Subsidence $(\mathrm{m})$} & & Time (My) & \multicolumn{2}{|c|}{ Subsidence (m) } & \\
\hline 108.7 & \multicolumn{2}{|c|}{2049} & & 108.7 & \multicolumn{2}{|c|}{1831} & \\
\hline 65.5 & \multicolumn{2}{|c|}{2162} & & 65.5 & 1945 & & \\
\hline \multicolumn{3}{|c|}{ ROLLAMIENTA well } & $\begin{array}{c}\mathrm{HF} \\
\left(\mathrm{mW} / \mathrm{m}^{2}\right.\end{array}$ & \multicolumn{3}{|c|}{ FUENTETOBA } & $\begin{array}{c}\mathrm{HF} \\
\left(\mathrm{mW} / \mathrm{m}^{2}\right)\end{array}$ \\
\hline \multicolumn{2}{|c|}{ Intial Subsidence (m) } & 1356 & \multirow{8}{*}{63} & \multicolumn{2}{|c|}{ Intial Subsidence (m) } & 1041 & \multirow{8}{*}{60} \\
\hline Time (My) & \multicolumn{2}{|c|}{ Subsidence $(\mathrm{m})$} & & Time (My) & \multicolumn{2}{|c|}{ Subsidence (m) } & \\
\hline 150.8 & \multicolumn{2}{|l|}{31} & & 150.8 & \multicolumn{2}{|l|}{31} & \\
\hline 108.7 & \multicolumn{2}{|c|}{1387} & & 108.7 & 1072 & & \\
\hline \multicolumn{3}{|c|}{ Thermal Subsidence (m) } & & \multicolumn{3}{|c|}{ Thermal Subsidence (m) } & \\
\hline Time (My) & \multicolumn{2}{|c|}{ Subsidence $(\mathrm{m})$} & & Time (My) & \multicolumn{2}{|c|}{ Subsidence $(\mathrm{m})$} & \\
\hline 108.7 & \multicolumn{2}{|c|}{1387} & & 108.7 & \multicolumn{2}{|c|}{1072} & \\
\hline 65.5 & \multicolumn{2}{|c|}{1511} & & 65.5 & \multicolumn{2}{|c|}{1201} & \\
\hline
\end{tabular}

\begin{tabular}{lllll} 
ID sample & Unit & $\begin{array}{c}\text { \%Ro } \\
\text { Mean }\end{array}$ & \%Ro Min & $\begin{array}{c}\text { \%Ro } \\
\text { Max }\end{array}$ \\
\hline ROB-OLI & DS8 - Oliván Gr & $\mathbf{3 . 2 0}$ & 3.03 & 3.52 \\
PR-11P & DS7 - Leza Fm & $\mathbf{3 . 5 0}$ & 1.94 & 5.60 \\
SEN-5 & DS7 - Enciso Gr & $\mathbf{2 . 4 0}$ & 2.20 & 5.10 \\
SEN-3 & DS7 - Enciso Gr & $\mathbf{3 . 8 8}$ & 3.10 & 5.70 \\
SEN-1 & DS7 - Enciso Gr & $\mathbf{2 . 0 9}$ & 1.80 & 2.30 \\
URB-2 & DS7 - Urbión Gr & $\mathbf{3 . 2 0}$ & 3.00 & 3.90 \\
SOY-3 & DS3 - Valdeprado Fm & $\mathbf{3}$ & 2.4 & 4.3 \\
SOH-4 & DS3 - Valdeprado Fm & $\mathbf{2 . 7}$ & 2.4 & 3.5 \\
SOO-2 & DS3 - Valdeprado Fm & $\mathbf{2 . 0 0}$ & 1.7 & 3.2 \\
SOO-1 & DS3 - Valdeprado Fm & $\mathbf{1 . 9}$ & 1.55 & 2.8 \\
TOR-2 & DS3 - Huerteles Fm & $\mathbf{4 . 6}$ & 3.7 & 6 \\
SHDL-1 & DS3 - Huerteles Fm & $\mathbf{2 . 9}$ & 2.7 & 3.2 \\
SPO-1 & DS1+2 Tera Gr & $\mathbf{3 . 5}$ & 3.1 & 3.7 \\
SPOV-7 & DS3 - Huerteles Fm & $\mathbf{3}$ & 2.07 & 3.47 \\
SPOV-3 & DS1 +2 Tera Gr & $\mathbf{2}$ & 1.3 & 2.8 \\
SPOV-1 & DS1+2 Tera Gr & $\mathbf{2 . 2}$ & 1.7 & 2.4 \\
PIG-1 & DS7 - Abejar Fm & $\mathbf{0 . 4 7}$ & 0.3 & 0.9 \\
STFC-4 & DS7 - Abejar Fm & $\mathbf{0 . 5 0}$ & 0.4 & 0.6 \\
STFC-1 & DS6 - Pantano Fm & $\mathbf{0 . 5 7}$ & 0.40 & 0.65
\end{tabular}

This article is protected by copyright. All rights reserved. 


\begin{tabular}{|c|c|c|c|c|c|c|c|c|}
\hline $\begin{array}{r}\text { Sa } \\
\text { mple }\end{array}$ & Unit & $\begin{array}{c}\begin{array}{c}\text { №meas } \\
\text { ure/sampl } \\
\text { e }\end{array} \\
\end{array}$ & Origin & Type & $\begin{array}{l}\text { Syste } \\
\text { m }\end{array}$ & $\begin{array}{l}\text { Th } \\
\min \\
{\left[\stackrel{\circ}{ }{ }^{\circ}\right]} \\
\end{array}$ & $\begin{array}{l}\text { Th } \\
\max \\
{\left[{ }^{\circ} \mathrm{C}\right]}\end{array}$ & $\begin{array}{r}\text { Th } \\
\text { mean } \\
{\left[{ }^{\circ} \mathrm{C}\right]} \\
\end{array}$ \\
\hline $\mathrm{Fl}-1$ & $\begin{array}{l}\text { DS3 - Huerteles } \\
\text { m }\end{array}$ & 19 & Primar & $\begin{array}{l}\text { Quartz } \\
\text { overgrowth } \\
\text { S }\end{array}$ & ${ }_{2} \mathrm{O}^{\mathrm{NaCl}+\mathrm{H}}$ & 111 & 168 & 120 \\
\hline $\mathrm{FI}-2$ & DS4 - Urbión Gr & 25 & Primar & $\begin{array}{l}\text { Quartz } \\
\text { vein }\end{array}$ & ${ }_{2} \mathrm{O}^{\mathrm{NaCl}+\mathrm{H}}$ & 121 & 299 & 290 \\
\hline
\end{tabular}

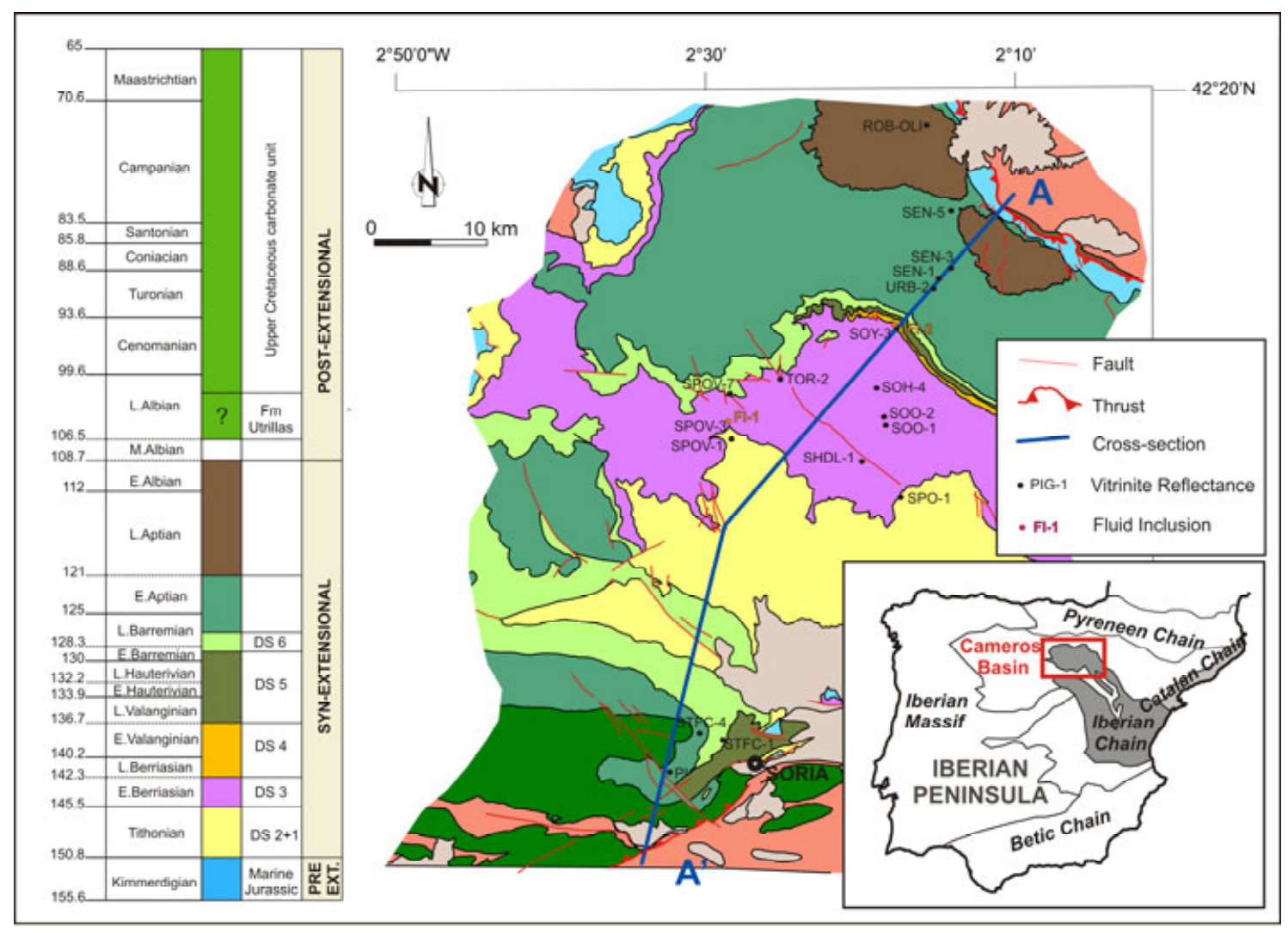

This article is protected by copyright. All rights reserved. 


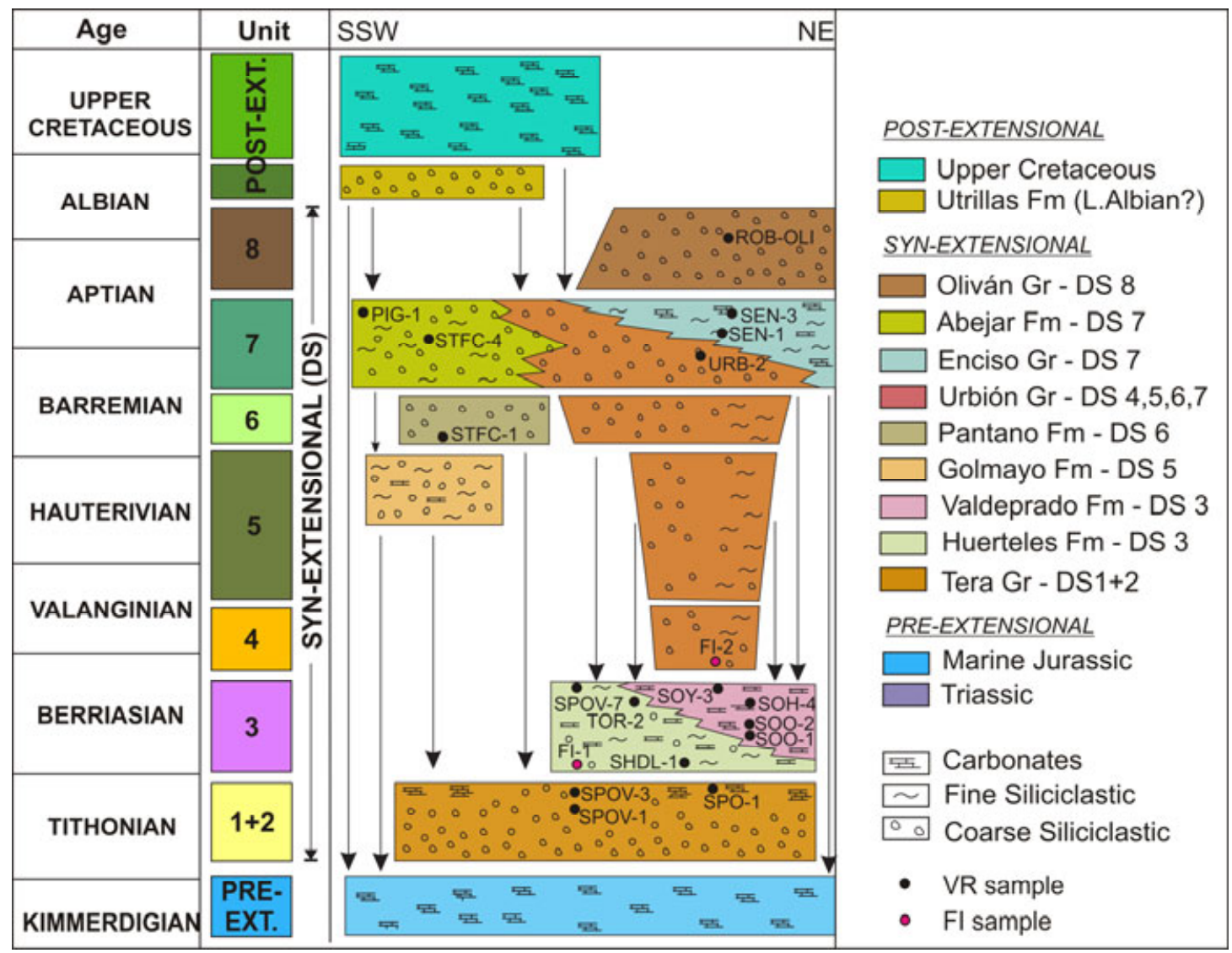

This article is protected by copyright. All rights reserved. 


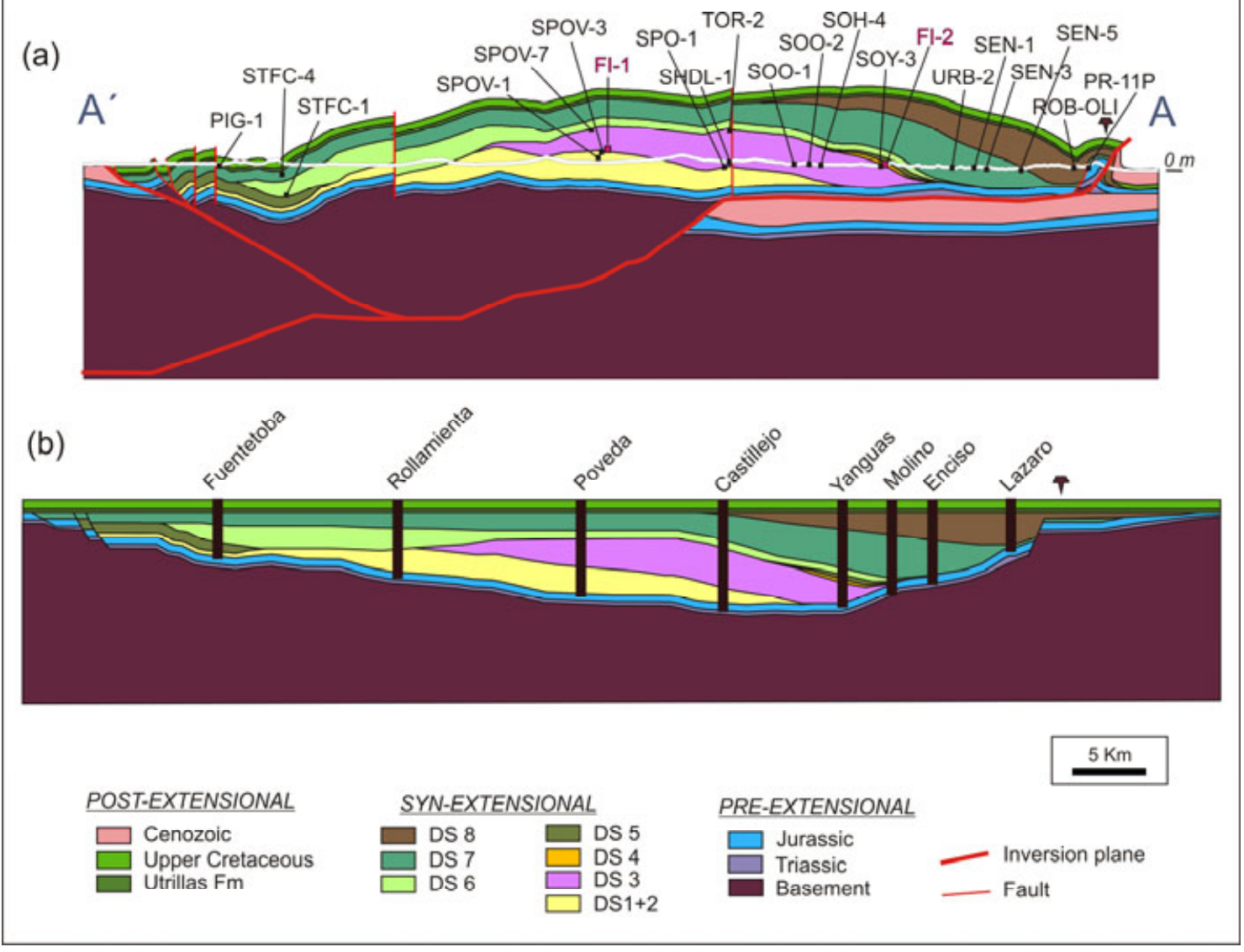

This article is protected by copyright. All rights reserved. 


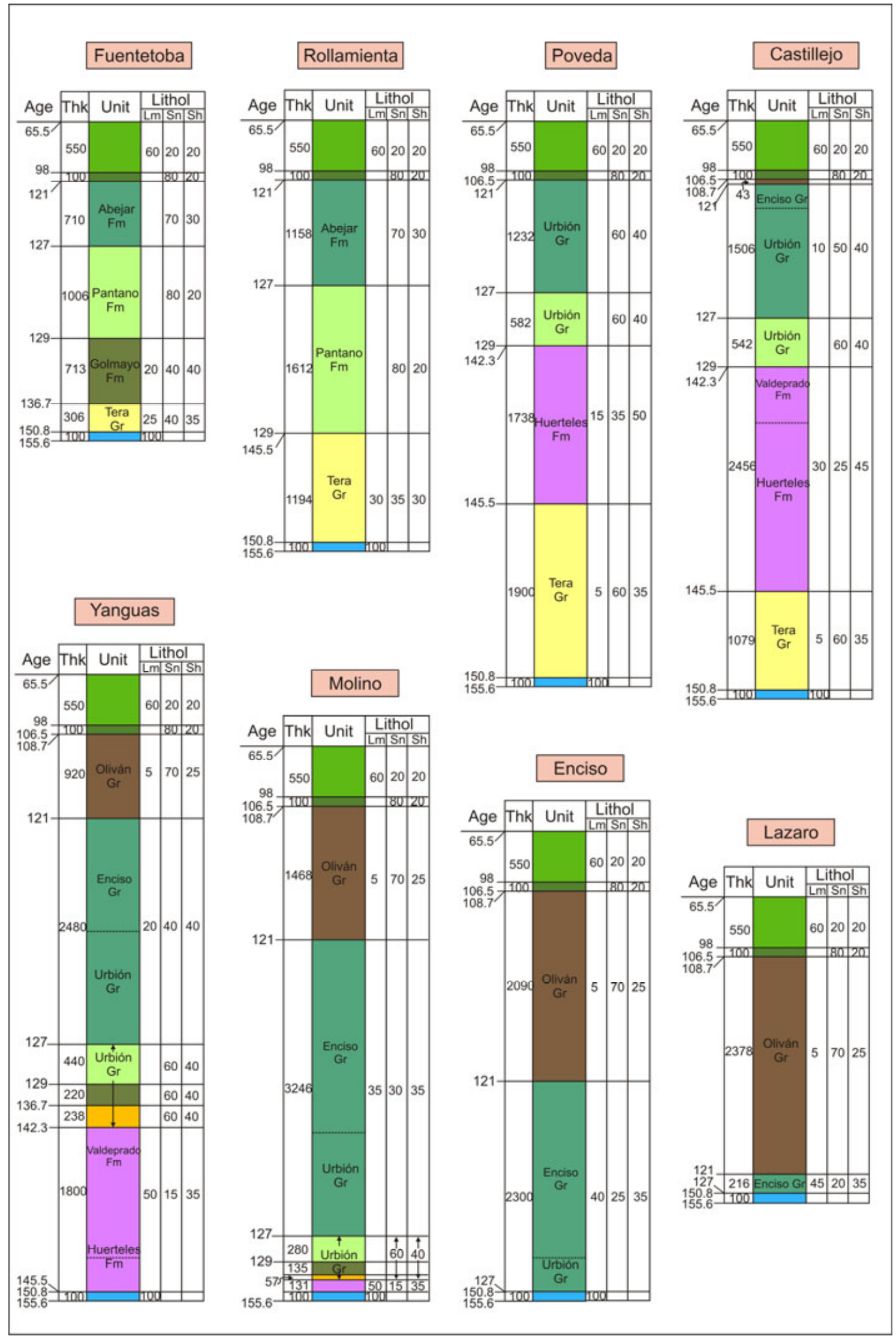

This article is protected by copyright. All rights reserved. 


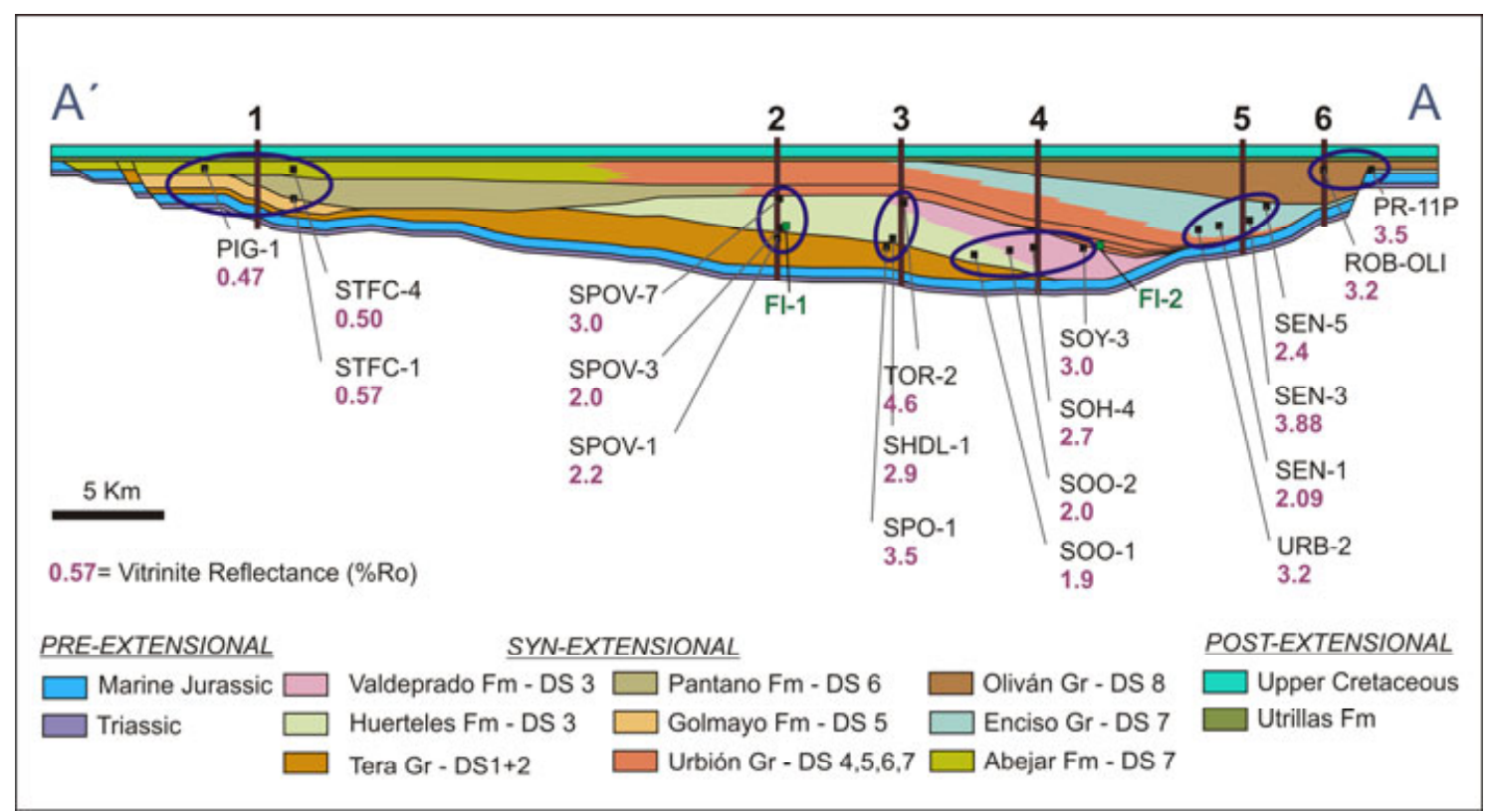

This article is protected by copyright. All rights reserved. 


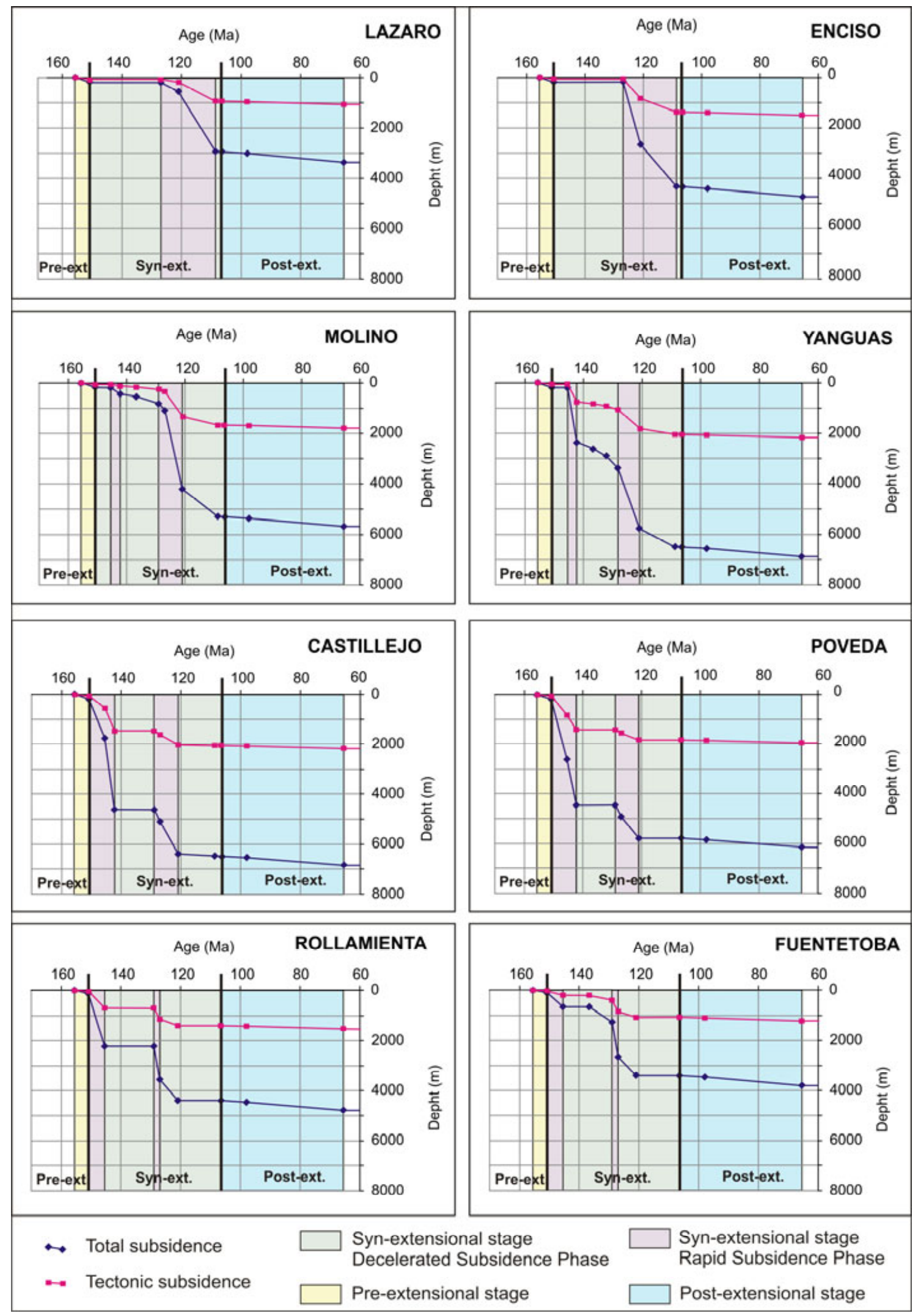

This article is protected by copyright. All rights reserved. 


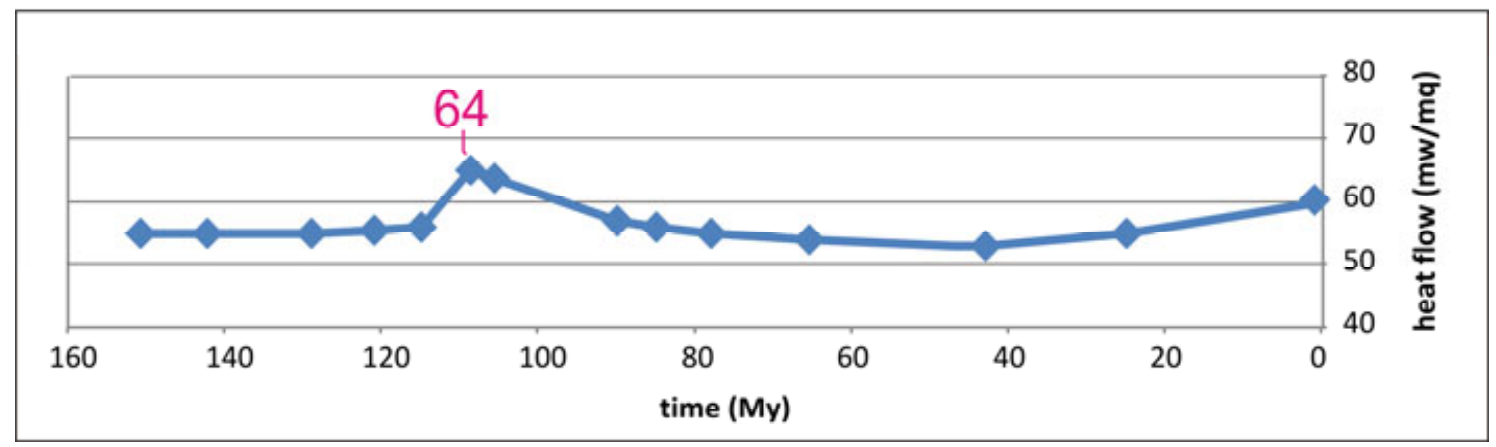

This article is protected by copyright. All rights reserved. 


$$
\overline{n i}
$$




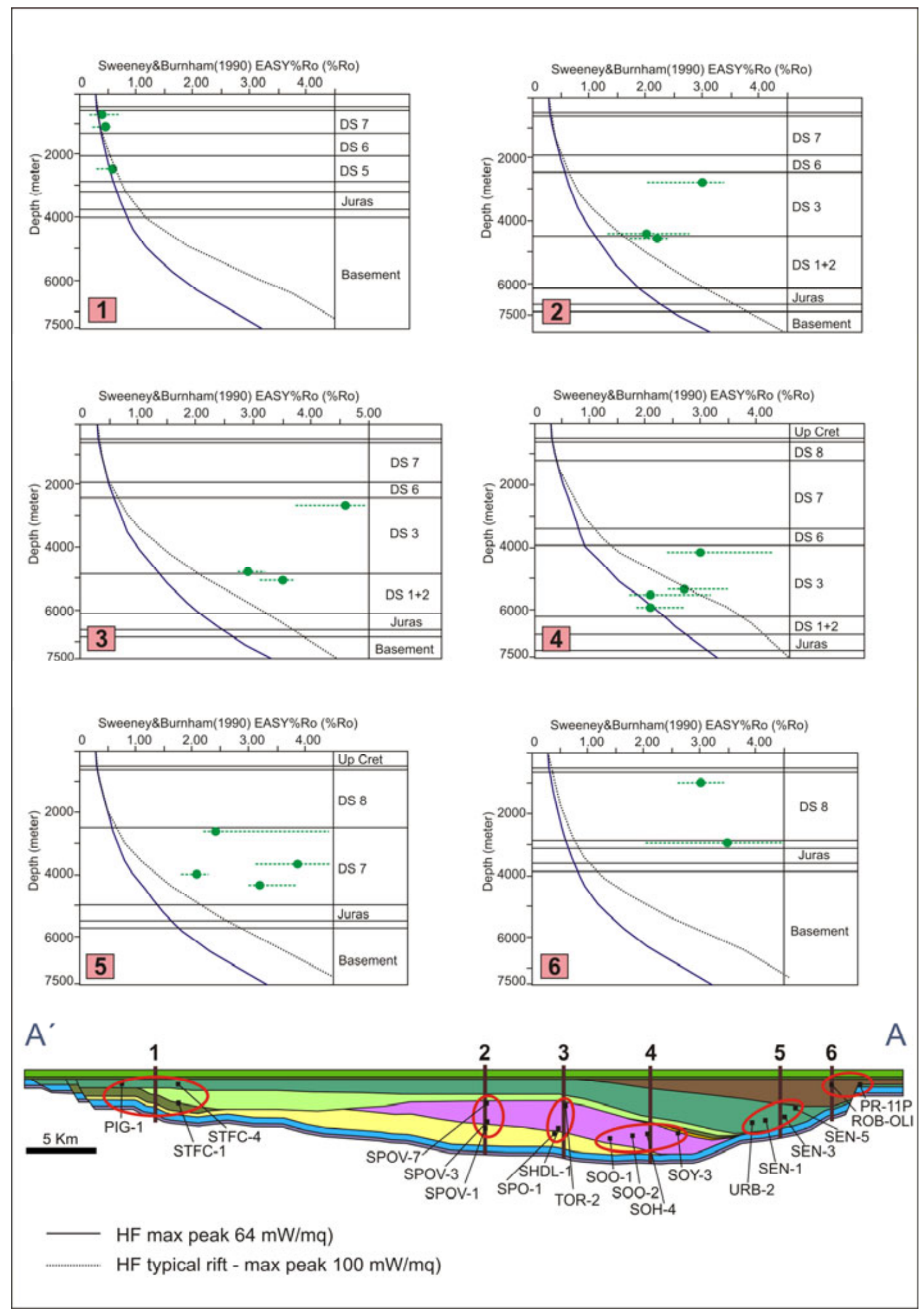

This article is protected by copyright. All rights reserved. 


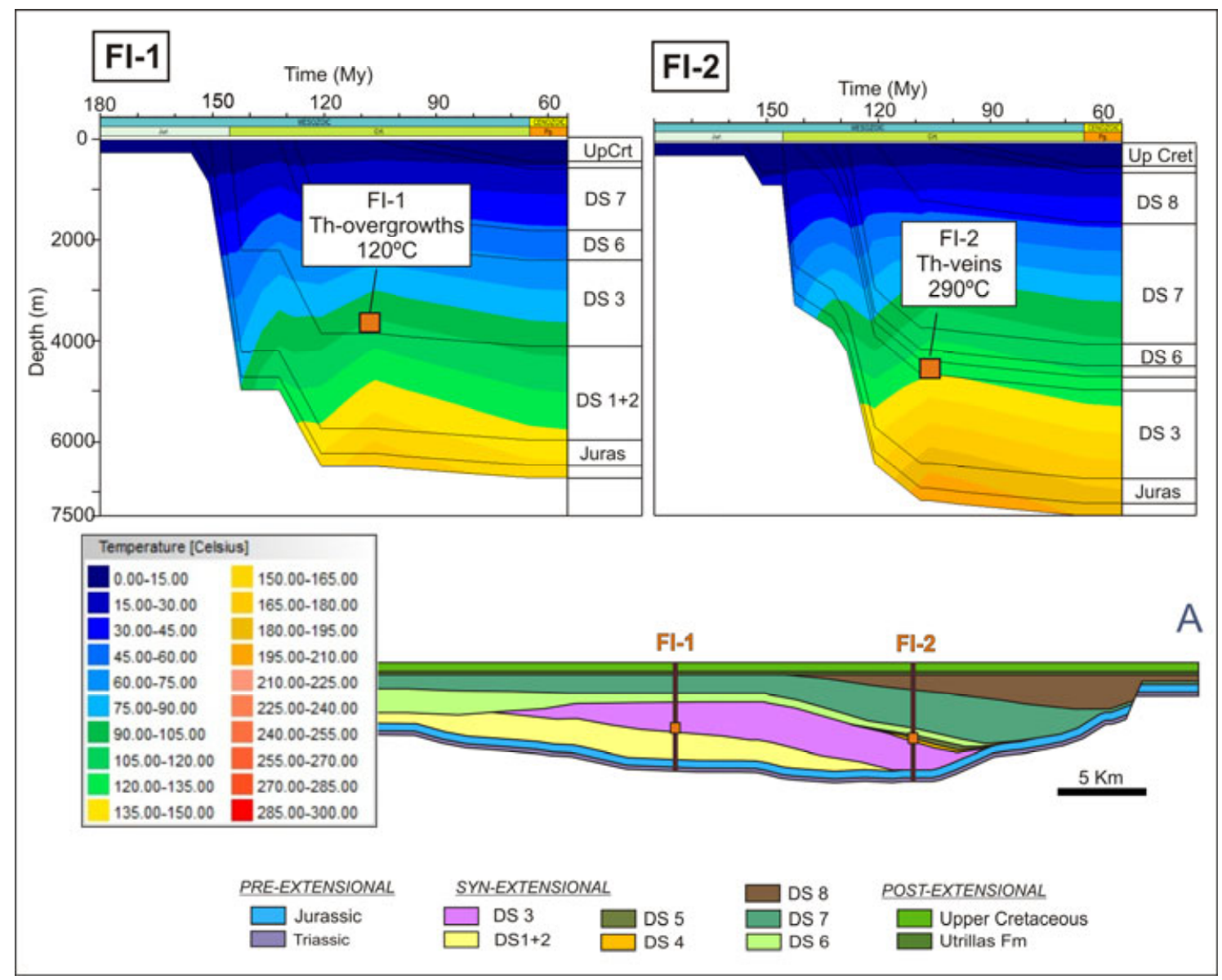

This article is protected by copyright. All rights reserved. 